\title{
Biogeochemical Controls on the Release and Accumulation of Mn and As in Shallow Aquifers, West Bengal, India
}

\author{
Michael A. Vega ${ }^{1}$, Harshad V. Kulkarni ${ }^{2}$, Natalie Mladenov ${ }^{3}$, Karen Johannesson ${ }^{4}$, \\ Ganga M. Hettiarachchi ${ }^{5}$, Prosun Bhattacharya ${ }^{6,7}$, Naresh Kumar ${ }^{8}$, Joseph Weeks ${ }^{5}$, \\ Madhubhashini Galkaduwa ${ }^{5}$ and Saugata Datta ${ }^{1 *}$
}

\begin{abstract}
${ }^{1}$ Department of Geology, Kansas State University, Manhattan, KS, United States, ${ }^{2}$ Department of Civil Engineering, Kansas State University, Manhattan, KS, United States, ${ }^{3}$ Department of Civil, Construction, and Environmental Engineering, San Diego State University, San Diego, CA, United States, ${ }^{4}$ Department of Earth and Environmental Sciences, Tulane University, New Orleans, LA, United States, ${ }^{5}$ Department of Agronomy, Kansas State University, Manhattan, KS, United States, ${ }^{6}$ KTH-International Groundwater Arsenic Research Group, Department of Sustainable Development, Environmental Science and Engineering, KTH Royal Institute of Technology, Stockholm, Sweden, ${ }^{7}$ International Center for Applied Climate Science, The University of Southern Queensland, Toowoomba, QLD, Australia, ${ }^{8}$ Department of Geological Sciences, Stanford University, Stanford, CA, United States
\end{abstract}

OPEN ACCESS

Edited by: Ondra Sracek,

Palacký University, Olomouc, Czechia

Reviewed by:

Marco Petitta,

Sapienza Università di Roma, Italy

Tomas Navratil,

Institute of Geology (ASCR), Czechia

*Correspondence: Saugata Datta sdatta@ksu.edu

Specialty section: This article was submitted to Groundwater Resources and Management,

a section of the journal Frontiers in Environmental Science

Received: 22 March 2017 Accepted: 29 May 2017

Published: 23 June 2017

Citation:

Vega MA, Kulkarni HV, Mladenov N, Johannesson K, Hettiarachchi GM Bhattacharya P, Kumar N, Weeks J,

Galkaduwa M and Datta S (2017)

Biogeochemical Controls on the Release and Accumulation of $\mathrm{Mn}$ and As in Shallow Aquifers, West Bengal,

India. Front. Environ. Sci. 5:29.

doi: 10.3389/fenvs.2017.00029

\section{HIGHLIGHTS}

- Manganese and arsenic concentrations are elevated in Murshidabad groundwater.

- Manganese release appears to be independent of dissolved organic matter quality.

- Mineral precipitation and dissolution reactions impact fate of manganese.

- Arsenic concentrations are related to dissolved organic matter quantity and quality.

The prevalence of manganese $(\mathrm{Mn})$ in Southeast Asian drinking water has recently become a topic of discussion, particularly when concurrent with elevated arsenic (As). Although Mn groundwater geochemistry has been studied, the link between dissolved organic matter (DOM) quality and $\mathrm{Mn}$ release is less understood. This work evaluates characteristics of DOM, redox chemistry, and the distribution of Mn within Murshidabad, West Bengal, India. Shallow aquifer samples were analyzed for cations, anions, dissolved organic carbon, and DOM properties using 3-dimensional fluorescence excitation emission matrices followed by parallel factor modeling analyses. Two biogeochemical regimes are apparent, separated geographically by the river Bhagirathi. East of the river, where $\mathrm{E}_{\mathrm{h}}$ and nitrate $\left(\mathrm{NO}_{3}^{-}\right)$values are low, humic-like DOM coexists with high dissolved $\mathrm{Mn}$, As, and Fe. West of the river, lower dissolved As and Fe concentrations are coupled with more protein-like DOM and higher $\mathrm{NO}_{3}^{-}$and $\mathrm{E}_{\mathrm{h}}$ values. Dissolved $\mathrm{Mn}$ concentrations are elevated in both regions. Based on the distribution of available electron acceptors, it is hypothesized that groundwater east of the Bhagirathi, which is more reducing and enriched in dissolved Fe and $\mathrm{Mn}$ but depleted in $\mathrm{NO}_{3}^{-}$, is chemically dominated by $\mathrm{Mn}(\mathrm{IV}) / \mathrm{Fe}(\mathrm{III})$ reduction processes. West of the river where $\mathrm{NO}_{3}^{-}$is abundant yet dissolved $\mathrm{Fe}$ is absent, $\mathrm{NO}_{3}^{-}$and $\mathrm{Mn}(\mathrm{IV})$ likely buffer redox conditions such that $\mathrm{E}_{\mathrm{h}}$ values are not sufficiently reducing to release $\mathrm{Fe}$ into the dissolved phase. The co-occurrence of humic-like 
DOM with dissolved $\mathrm{As}$, Fe, and $\mathrm{Mn}$ in the more reducing aquifers may reflect complex formation between humic DOM and metals, as well as electron shuttling processes involving humic DOM, which may enhance metal(loid) release. Saturation indices of rhodochrosite $\left(\mathrm{MnCO}_{3}\right)$ suggest that precipitation is thermodynamically favorable in a greater proportion of the more reducing sites, however humic DOM-Mn complexes may be inhibiting $\mathrm{MnCO}_{3}$ precipitation. Where dissolved arsenic concentrations are low, it is postulated that $\mathrm{Mn}(\mathrm{IV})$ reduction is oxidizing $\mathrm{As}(\mathrm{III})$ to $\mathrm{As}(\mathrm{V})$, increasing the potential for re-adsorption of $A s(V)$ onto relatively stable, un-reduced or newly precipitated Fe-oxides. Manganese release appears to be independent of DOM quality, as it persists in both humic and protein-like DOM environments.

Keywords: manganese, organic matter, West Bengal, arsenic, shallow aquifer

\section{INTRODUCTION}

Throughout the Bengal Basin, elevated levels of manganese (Mn) and arsenic (As) have adversely impacted groundwater quality, prompting serious concerns to human health (Bhattacharya et al., 1997; Nickson et al., 1998; BGS and DPHE, 2001; Buschmann et al., 2008; Datta et al., 2009, 2011; Frisbie et al., 2009; Farooq et al., 2011; Sankar et al., 2014; Datta, 2015; Shrivastava et al., 2015; Kshetrimayum and Hegeu, 2016). Further, groundwater is the primary source of drinking water in many of these regions due to surface waters being contaminated by anthropogenic waste (McArthur et al., 2012a).

Although $\mathrm{Mn}$ is an essential trace nutrient, it has been reported to cause negative health effects when consumed in excess, including adverse impacts on maternity and birth outcomes (Yazbeck et al., 2006; Barrett, 2007; Hafeman et al., 2007; Grazuleviciene et al., 2009; Ljung et al., 2009; Spangler and Spangler, 2009; Wood, 2009; Zota et al., 2009), inhibiting the intellectual development of children (Woolf et al., 2002; Wasserman et al., 2006, 2008, 2011; Bouchard et al., 2011; Khan et al., 2012) and neurological problems associated with Parkinson's-like symptoms (Barceloux, 1999; Ono et al., 2002; Bouchard et al., 2007; Avelino et al., 2014). Many of these ailments have been documented in the Bengal Basin (Wasserman et al., 2006, 2008, 2011; Barrett, 2007; Hafeman et al., 2007; Ljung et al., 2009; Khan et al., 2012).

The Bureau of Indian Standards (BIS) has enforced an Acceptable Limit for $\mathrm{Mn}$ in drinking water of $0.1 \mathrm{mg} \mathrm{L}^{-1}$, and $0.3 \mathrm{mg} \mathrm{L}^{-1}$ in the absence of an alternative drinking water source (BIS, 2012); however, it has been suggested that the Mn limit may be practically difficult to achieve, given the naturally occurring concentrations of $\mathrm{Mn}$ in groundwater. Further, the World Health Organization (WHO, 2011) revoked the guideline for acceptable $\mathrm{Mn}$ in drinking water of $0.4 \mathrm{mg} \mathrm{L}^{-1}$ because it was well above concentrations of Mn normally found in drinking water. Ljung and Vahter (2007) argued that $0.4 \mathrm{mg} \mathrm{L}^{-1}$ was originally too high, and numerous studies have suggested a re-evaluation of the guideline for $\mathrm{Mn}$ is required (Biswas et al., 2012a,b; Frisbie et al., 2012; McArthur et al., 2012b).

Manganese (II) is the most common Mn species in acidic to circumneutral $\mathrm{pH}$ groundwater, as it is more soluble than Mn(III) or Mn(IV) (Tebo et al., 2007). Whereas the precipitation of insoluble $\mathrm{Mn}(\mathrm{III})-\mathrm{Mn}(\mathrm{IV})$ - oxy (hydroxides) at higher $\mathrm{pH}$ (Hem, 1985) is thermodynamically favorable, the activation energy is high and hence the reaction is slow in nature (Gounot, 1994). The biological oxidation of Mn(II) (Tebo et al., 1997), however, is kinetically favorable and has been shown to produce stable Mn(IV) bio-oxides (Tebo et al., 2004) that predominate in natural systems. Such Mn oxides are known to strongly adsorb As species in a similar fashion to Fe oxides (Morgan and Stumm, 1964; Young and Harvey, 1992; Manning et al., 2002; Deschamps et al., 2003; Foster et al., 2003; Toner et al., 2006; Wu et al., 2015). Furthermore, Mn(IV)—oxides can oxidize As(III) to $\mathrm{As}(\mathrm{V})$, limiting As mobility and toxicity (Golden et al., 1986). Arsenic-Mn precipitates have also been shown to form under such biogeochemical conditions (Tournassat et al., 2002).

Thermodynamically, $\mathrm{Mn}(\mathrm{IV})$ is a more favored terminal electron acceptor than $\mathrm{Fe}(\mathrm{III})$ by anaerobic microorganisms (Stumm and Morgan, 1981; McGuire et al., 2002; Bethke et al., 2011), and $\mathrm{Mn}$ (II) is mobilized as a result of reductive dissolution of Mn(IV) —oxides (Appelo and Postma, 2005; Buschmann et al., 2007). Further, the mobility of $\mathrm{Mn}$ (II) can be influenced by the precipitation of carbonate, sulfide, or phosphate phases (Nickson et al., 2000; McArthur et al., 2001; Buschmann et al., 2007; Nath et al., 2009; Sankar et al., 2014), sorption of Mn(II) onto sediment surfaces (Wersin et al., 1989), as well as complexation with dissolved organic matter (DOM) (Marshall, 1979; Gavin et al., 2001; Graham et al., 2002).

The influence of DOM on the geochemistry of trace metals has been documented extensively (Lovley and Phillips, 1988; Nealson and Saffarini, 1994; Lovley et al., 1996; Nickson et al., 2000; Smedley and Kinniburgh, 2002). Microbially mediated reductive dissolution of $\mathrm{Mn}(\mathrm{IV}) / \mathrm{Fe}(\mathrm{III})$ oxides in the presence of labile organic carbon has been shown to cause elevated levels of dissolved $\mathrm{Mn}(\mathrm{II}), \mathrm{As}(\mathrm{III})$, and $\mathrm{Fe}(\mathrm{II})$ in the groundwater of the Bengal Basin (Dowling et al., 2002; Smedley and Kinniburgh, 2002; Lovley et al., 2004; McArthur et al., 2004). Recently, multiple roles of biologically refractive (humic-like) DOM such as aqueous complexation (Sharma et al., 2010; Liu et al., 2011) and electron shuttling (Lovley et al., 1996, 1998, 1999; Scott et al., 1998; Kappler et al., 2004; Jiang and Kappler, 2008; Wolf et al., 2009; Mladenov et al., 2010, 2015) have been implicated in the mobilization of redox sensitive elements such as Fe and As. Formation of $\mathrm{Mn}-$ humic complexes have been shown to inhibit 
the adsorption of $\mathrm{Mn}$ in near surface environments (Gavin et al., 2001; Graham et al., 2002). Lovley et al. (1996) showed that the model humic substance (AQDS) was capable of shuttling electrons from anaerobic microorganisms to Fe(III) - oxides, and it was suggested that these findings were similar for Mn(IV) oxides, yet no study to date has directly confirmed this. In addition, Mn(IV)-oxides have been shown to oxidize phenols to produce humic-like substances (Vodyanitskii, 2009), and lyse high molecular weight (HMW) biologically refractive humic and fulvic acids into low molecular weight (LMW) biologically labile organic compounds such as pyruvate, which can serve as an electron donor for microorganisms (Sunda and Kieber, 1994).

Absorbance and fluorescence spectroscopic techniques have been widely used to characterize chromophoric DOM sources and transformations. Three-dimensional excitation emission matrices (EEMs) contain fluorophores associated with DOM derived from both microbial and higher plant sources. In addition to evaluation of fluorescence peaks (Coble, 1996) and indices (Parlanti et al., 2000; Ohno, 2002; Zsolnay, 2003; Cory and McKnight, 2005; Hansen et al., 2016) found in the EEMs, fluorescence data can be further analyzed using a parallel factor (PARAFAC) multivariate modeling analysis. PARAFAC modeling of large EEM datasets identifies the underlying fluorescence components that comprise an EEM. PARAFAC models also provide concentrations and relative distributions of each modeled component in each sample. These techniques have been used to discriminate unique fluorescence components and investigate potential sources of DOM (Stedmon et al., 2003; Stedmon and Bro, 2008; Williams et al., 2013).

The quality of DOM and its potential roles in As mobilization have been investigated using a range of fluorescence and absorbance spectroscopic techniques in Bangladesh (Mladenov et al., 2010, 2015). Further, a PARAFAC model developed using samples from the same sites as in this study (West Bengal, India) identified four unique components, namely terrestrial humic-like, humic-like impacted by agriculture, protein-like, and microbial humic-like (Kulkarni et al., 2016). The association of DOM with Mn mobilization from aquifer sediments has not been examined to date. The objective of this study was therefore to highlight associations between $\mathrm{Mn}$ and As biogeochemistry in conjunction with DOM quality in the shallow groundwater of West Bengal, India.

\section{MATERIALS AND METHODS}

\section{Study Site}

A total of 51 groundwater and 16 sediment samples were collected from 2 sites located on the west side (Nabagram and Kandi) and 4 sites located on the east side (Hariharpara, Beldanga, Naoda, and Khidirpur) of the North-South flowing river Bhagirathi in Murshidabad to investigate the biogeochemistry of $\mathrm{Mn}$ (Figure 1). Murshidabad is a district $\left(\sim 5,500 \mathrm{~km}^{2}\right)$ in north-central West Bengal with a population of $\sim 7.1$ million (Census of India, 2011).

Distinct geological settings on the east and west sides of the river Bhagirathi have been previously discussed in Datta et al. (2011), Sankar (2013), Sankar et al. (2014), and Kulkarni et al.
(2016). Briefly, the geology of the sites located east of the river Bhagirathi consists of young Holocene sediments $(\sim 7,000$ years before present), whereas Pleistocene sediments $(12,300-48,600$ years before present) occur to the west of the river (Acharya et al., 2000; Mukherjee et al., 2007; Neidhardt et al., 2013). The permeability of Holocene sands east of the river Bhagirathi is reported to be $40-60 \mathrm{~m} \mathrm{~d}^{-1}$, whereas the permeability of the Pleistocene sediments to the west are reported to be slightly lower (i.e., 20-30 $\mathrm{m} \mathrm{d}^{-1}$; Mukherjee et al., 2007). The lower permeability of the Pleistocene sediments is attributed to the presence of secondary clays and iron oxides, which are thought to clog pore spaces within the sands (Ravenscroft et al., 2005).

Several studies have reported higher Fe and As concentrations in groundwater from the Holocene aquifers (Mukherjee and Bhattacharya, 2001; Bhattacharya et al., 2002; Datta et al., 2011; Sankar, 2013; Sankar et al., 2014), whereas lower Fe and As concentrations have been observed in groundwater from the Pleistocene aquifers (Datta et al., 2011; Hoque et al., 2011; Sankar et al., 2014; Kulkarni et al., 2016). The contrasting DOM quality at Hariharpara, Beldanga, Nabagram, and Kandi sites has been discussed in Kulkarni et al. (2016), who demonstrated the presence of more humic-like DOM in Hariharpara and Beldanga compared to Nabagram and Kandi.

\section{Sample Collection and Storage}

Groundwater samples were collected at various depths from drinking water tube wells at Nabagram ( $n=8,27-43 \mathrm{~m}$ depth), Kandi ( $n=6,21-37 \mathrm{~m}$ depth), Hariharpara ( $n=12,12-25 \mathrm{~m}$ depth), Beldanga ( $n=13,18-40 \mathrm{~m}$ depth), Naoda $(n=10,18-$ $40 \mathrm{~m}$ depth) and Khidirpur ( $n=2,8 \mathrm{~m}$ depth) in January of 2010 (Sankar et al., 2014) and later in January of 2015. After pumping and purging each well for $\sim 15 \mathrm{~min}$, groundwater samples were collected in acid washed HDPE bottles pre-rinsed three times with the collected sample.

Field parameters such as $\mathrm{pH}, \mathrm{E}_{\mathrm{h}}$ ( $\mathrm{Ag} / \mathrm{AgCl}$ adjusted to standard hydrogen electrode (SHE)), temperature, electrical conductivity, salinity, and total dissolved solids (TDS) were measured immediately after the sample was collected in a clean 5-gallon HDPE bucket using portable probes (HACH HQ11D and Mettler Toledo SG3). The samples were filtered using a $0.45 \mu \mathrm{m}$ nitrocellulose membrane filter and acidified in the field using Optima Grade $\mathrm{HNO}_{3}(0.2 \% \mathrm{v} / \mathrm{v})$ for the analysis of cations $\left(\mathrm{Mn}_{\mathrm{T}}, \mathrm{Fe}_{\mathrm{T}}, \mathrm{As}_{\mathrm{T}}, \mathrm{Ca}^{2+}, \mathrm{Mg}^{2+}\right)$ by high resolution inductively coupled plasma mass spectrometry (HR-ICP-MS). Filtered and unacidified samples were used for the analysis of anions $\left(\mathrm{Cl}^{-}\right.$, $\mathrm{Br}^{-}, \mathrm{F}^{-}, \mathrm{SO}_{4}^{2-}, \mathrm{NO}_{3}^{-}$, and $\mathrm{PO}_{4}^{3}$ ) by ion chromatography (IC). All collected samples were placed immediately on ice and preserved throughout transport to Kansas State University.

Dissolved organic carbon (DOC) and total dissolved nitrogen (TDN) concentrations were determined using a thermic oxidation method on a Shimadzu TOC/TN 5050A analyzer. The samples were filtered in the field using pre-combusted $\left(4 \mathrm{~h}, 450^{\circ} \mathrm{C}\right) 0.7 \mu \mathrm{m}$ glass fiber filters (GFF) to avoid the risk of leaching organics from filters (such as nitrocellulose filters). Filtered samples were acidified in the field using Optima Grade $\mathrm{HCl}(0.2 \% \mathrm{v} / \mathrm{v})$ to inhibit microbial activity (Burdige and Homstead, 1994; Tupas et al., 1994; Burdige 


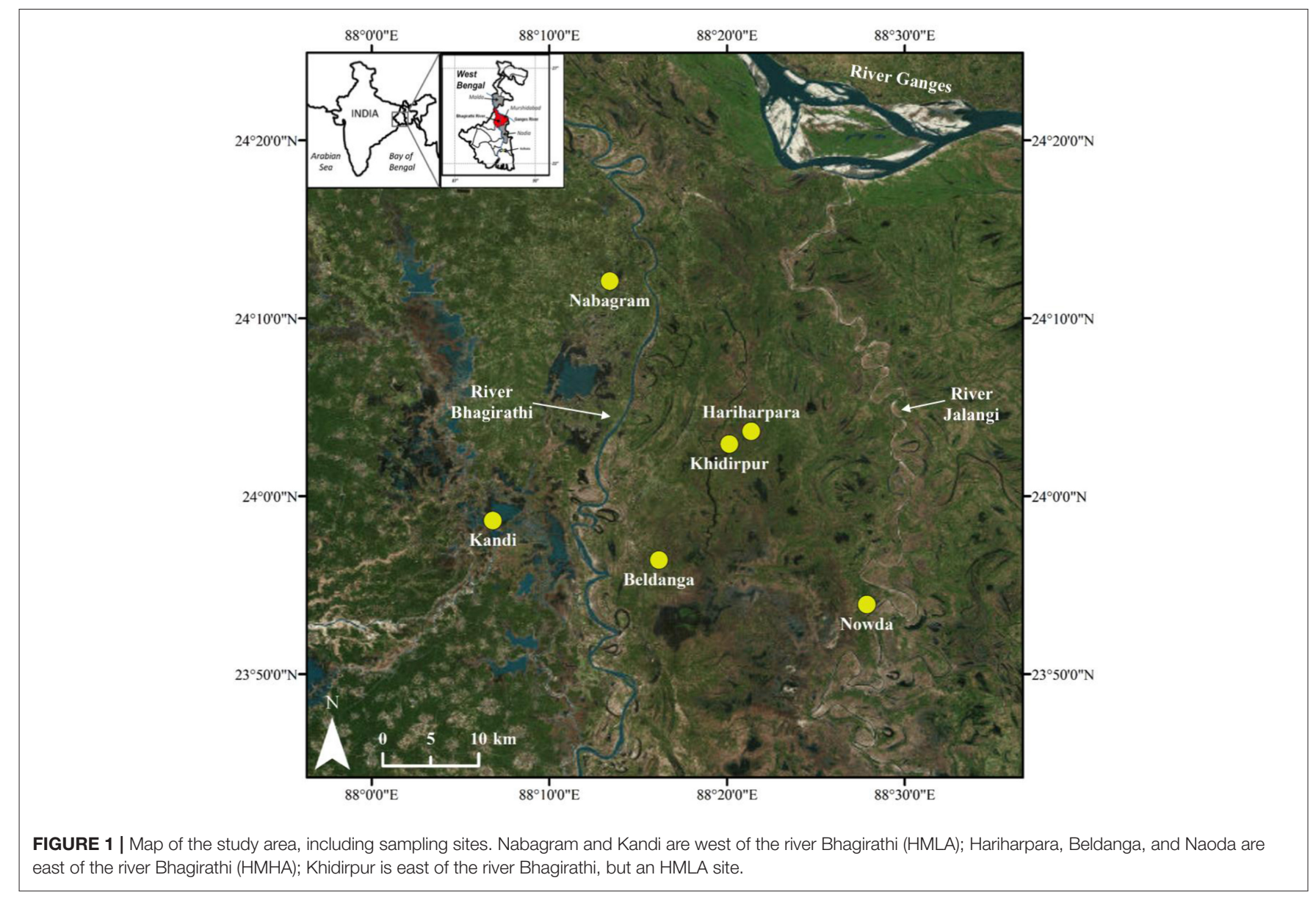

and Gardner, 1998). Spectral characterization (absorbance and fluorescence) of DOM was conducted on a Jobin Yvon Horiba Aqualog benchtop fluorometer, using $0.7 \mu \mathrm{m}$ GFF filtered but unacidified samples to avoid fluorescence quenching effects at $\mathrm{pH}$ lower than the natural $\mathrm{pH}$ of the sample (Spencer et al., 2007).

Sediment cores were collected at the time of sampling by locally hired drillers using the percussion hand drilling method. Samples were collected in PVC tubes in incremental depths ranging between $\sim 10$ and $40 \mathrm{~m}$, followed by preservation in $\mathrm{O}_{2}$-impermeable Remel ${ }^{\circledR}$ bags (Mitsubishi Gas Company, Remel ${ }^{\circledR}$, Cat no. 2019-11-02), along with $\mathrm{O}_{2}$ absorber pouches (Mitsubishi Gas Company, AnaeroPouch ${ }^{\circledR}$ Anaero; Cat no. 23246-379), flushed with high-purity $\mathrm{N}_{2}$ gas, sealed, and shipped on ice to Kansas State University. Bulk $\mathrm{Mn}$, As, and $\mathrm{Fe}$ concentrations in sediments were acquired via a bulk digestion method modified from Premarathna et al. (2010). Briefly, $\sim 0.5 \mathrm{~g}$ of finely homogenized $(<2 \mathrm{~mm})$ sediments were treated in glass digestion tubes with $2.5 \mathrm{~mL}$ of $30 \% \mathrm{H}_{2} \mathrm{O}_{2}$ for $10 \mathrm{~min}$, followed by an additional $0.5 \mathrm{~mL}$ of $30 \% \mathrm{H}_{2} \mathrm{O}_{2}$, and allowed to react for $12 \mathrm{~h}$. The samples were then digested at $90^{\circ} \mathrm{C}$ until the volume reduced to $\sim 1 \mathrm{~mL}$. To this, $2.5 \mathrm{~mL}$ of freshly prepared aqua regia $\left(1: 3, \mathrm{HNO}_{3}: \mathrm{HCl}\right)$ was added and left to react for $12 \mathrm{~h}$. Samples were heated to $75^{\circ} \mathrm{C}(30 \mathrm{~min}), 90^{\circ} \mathrm{C}(30 \mathrm{~min}), 110^{\circ} \mathrm{C}$ (30 min) and then to $140^{\circ} \mathrm{C}$ until the total volumes were reduced to $\sim 1 \mathrm{~mL}$. Samples were diluted to $10 \mathrm{~mL}$ using Optima Grade
$0.1 \% \mathrm{HNO}_{3}$, filtered through $2.5 \mu \mathrm{m}$ (Whatman 42) filter paper and analyzed for $\mathrm{Fe}_{\mathrm{T}}$ and $\mathrm{Mn}_{\mathrm{T}}$ by a Varian 720-ES Inductively Coupled Plasma-Optical Emission Spectrometer (ICP-OES) and for As $s_{\mathrm{T}}$ by Varian GTA 120 Graphite Tube Atomizer w/ AA 240Z Zeeman Atomic Absorption Spectrometer (GTA-AAS). Three NIST standards (Montana II) were digested and yields of $101 \%$ (As), $84 \%(\mathrm{Fe})$, and $88 \%(\mathrm{Mn})$ obtained. To minimize potential losses, $30 \mathrm{~cm}$ digestion tubes with constricted necks were utilized. Lower Fe and Mn yields were probably attributed to Fe and Mn binding to siliceous materials, which are not readily dissociated by aqua regia (Loeppert and Inskeep, 1996).

\section{Fluorescence Analyses of DOM}

Spectral acquisition for fluorescence analyses was performed using an excitation range of $240-450 \mathrm{~nm}$ in $3 \mathrm{~nm}$ increments and an emission range of $300-600 \mathrm{~nm}$ in $3.28 \mathrm{~nm}$ increments (instrument default) with an integration time of 0.25 seconds. Absorbance was simultaneously measured on the same instrument from 300 to $600 \mathrm{~nm}$ in $3 \mathrm{~nm}$ increments. Filtered samples were brought to room temperature prior to fluorescence and absorbance measurements. Ultrapure water $(18.3 \mathrm{M} \Omega \cdot \mathrm{cm}$ Milli-Q) was used for Raman normalization (emission intensity at $350 \mathrm{~nm}$ ) and for blank subtraction. Inner filter effect corrections were done using the absorbance of each sample. Detailed information on instrumental parameters and data 
processing is described elsewhere (Kulkarni et al., 2016). Corrected EEMs of 51 samples were fitted to a four component PARAFAC model which was validated by split half analysis and random initialization technique using the DOMFluor toolbox (Stedmon and Bro, 2008).

Indices based on fluorescence and absorbance properties are useful in deciphering the quality of DOM in aqueous environments. The absorbance at $254 \mathrm{~nm}\left(\mathrm{Abs}_{254}\right)$ provides insight regarding the degree of aromaticity of DOM, particularly when normalized to DOC concentration and the path length of incident light as specific UV absorbance $\left(\mathrm{SUVA}_{254}\right.$ ) (Weishaar et al., 2003). The ratio of the absorption spectral slopes between 275 and $295 \mathrm{~nm}\left(\mathrm{~S}_{275-295}\right)$ and 350 and $400 \mathrm{~nm}\left(\mathrm{~S}_{350-400}\right)$, or $S_{R}$, was calculated to determine whether DOM was marine-like $\left(\mathrm{S}_{R}<1\right)$ or terrestrially dominated with high chromophoric dissolved organic matter (CDOM) $\left(S_{R}>1\right)$ (Helms et al., 2008). Freshness index $(\beta: \alpha)$ was calculated as the ratio of emission intensity at $380 \mathrm{~nm}$ to the maximum intensity between 420 and $435 \mathrm{~nm}$ at an excitation wavelength of $310 \mathrm{~nm}$ (Parlanti et al., 2000); lower values signify a greater extent of DOM decomposition (Wilson and Xenopoulos, 2008; Fellman et al., 2010). Fluorescence index (FI), the ratio of fluorescence intensities at 470 and $520 \mathrm{~nm}$ emission and at an excitation wavelength of $370 \mathrm{~nm}$, was calculated to understand the source of DOM. Higher FI's $(\sim 1.7-1.9)$ represent microbial derivation pathways and lower FI's $(\sim 1.3-1.4)$ imply a terrestrial origin (McKnight et al., 2001; Cory and McKnight, 2005). To measure the extent to which DOM has undergone humification, the humification index (HIX) was computed as the ratio of peak area under the emission spectra at 435 to $480 \mathrm{~nm}$ to the peak area from 300 to $345 \mathrm{~nm}$ at an excitation wavelength of $254 \mathrm{~nm}$ (Zsolnay, 2003).

\section{Equilibrium Chemical Speciation and Modeling}

Aqueous geochemical modeling was performed using Visual MINTEQ ver. 3.1 to calculate the equilibrium distribution and relevant saturation indices for $\mathrm{Mn}$ and $\mathrm{Fe}$ species. Arsenic speciation from groundwater within the same sites as this study was assessed previously by passing acidified samples through anion exchange columns, analyzing the eluent $\left(\mathrm{H}_{3} \mathrm{AsO}_{3}{ }^{0}\right)$ via HR-ICP-MS as As(III), then back-calculating from AsT to obtain As(V) (Sankar et al., 2014).

\section{Statistical Analyses}

Correlations were assessed by computing two-tailed Pearson correlation coefficients and the Mann-WhitneyWilcoxon (MWW) $U$ test was used to delineate statistically significant variability among groups due to a non-parametric distribution of parameters and a relatively small sample size. All statistical analyses were performed using SPSS Statistics Software. Parenthetic values represent the mean $\pm 95 \%$ confidence interval, and only correlations of statistical significance $(p<0.05)$ are presented.

\section{RESULTS}

\section{Hydrochemistry of Dissolved Mn, As, and Fe in Groundwater}

Of the 51 tube wells sampled, $73 \%$ contained total dissolved $\mathrm{Mn}$ $\left(\mathrm{Mn}_{\mathrm{T}}\right)>0.4 \mathrm{mg} \mathrm{L}^{-1}$ (revoked (WHO, 2011) guideline), $78 \%$ contained total dissolved As $\left(\mathrm{As}_{\mathrm{T}}\right)>10 \mu \mathrm{g} \mathrm{L}^{-1}(\mathrm{WHO}, 2011$ guideline), and $57 \%$ exceeded both of these guidelines (Figure 2, Figure S1). Only $6 \%$ of wells had $\mathrm{Mn}_{\mathrm{T}}<0.4 \mathrm{mg} \mathrm{L}^{-1}$ and $\mathrm{As}_{\mathrm{T}}$ $<10 \mu \mathrm{g} \mathrm{L}^{-1}$. Typically, high $\mathrm{Mn}_{\mathrm{T}}\left(0.83 \pm 0.14 \mathrm{mg} \mathrm{L}^{-1}\right)$ and high $\mathrm{As}_{\mathrm{T}}\left(330 \pm 97 \mu \mathrm{g} \mathrm{L}^{-1}\right)$ concentrations were observed in the tube wells located to the east of the river Bhagirathi and these sites are termed as HMHA sites for further discussion (Table 1). Conversely, high $\mathrm{Mn}_{\mathrm{T}}\left(1.1 \pm 0.29 \mathrm{mg} \mathrm{L}^{-1}\right)$ and low $\mathrm{As}_{\mathrm{T}}(9.0$ $\pm 2.1 \mu \mathrm{g} \mathrm{L}^{-1}$ ) concentrations were observed (Table 1) in the tube wells located to the west of the river (HMLA). The total Fe concentrations $\left(\mathrm{Fe}_{\mathrm{T}}\right)$ at HMHA sites $\left(3.6 \pm 0.93 \mathrm{mg} \mathrm{L}^{-1}\right)$ were significantly higher than at HMLA sites $\left(0.31 \pm 0.10 \mathrm{mg} \mathrm{L}^{-1}\right)$ (Table 1). The difference between $\mathrm{As}_{\mathrm{T}}$ and $\mathrm{Fe}_{\mathrm{T}}$ concentrations at the HMHA and HMLA sites was found to be statistically significant, but insignificant for $\mathrm{Mn}_{\mathrm{T}}$ concentrations (Table 1). Nitrate $\left(\mathrm{NO}_{3}^{-}\right)$and sulfate $\left(\mathrm{SO}_{4}^{2-}\right)$ values were significantly higher in HMLA $\left(2.8 \pm 3.0 \mathrm{mg} \mathrm{NO}_{3}^{-} \mathrm{L}^{-1} ; 16 \pm 9.7 \mathrm{mg} \mathrm{SO}{ }_{4}^{2-}\right.$ $\left.\mathrm{L}^{-1}\right)$ groundwater than in HMHA $\left(0.21 \pm 0.30 \mathrm{mg} \mathrm{NO}_{3}^{-} \mathrm{L}^{-1} ; 5.0\right.$ $\pm 2.8 \mathrm{mg} \mathrm{SO}_{4}^{2-} \mathrm{L}^{-1}$ ) groundwater (Table 1). Khidirpur, despite being east of the river Bhagirathi, showed exceptionally low $\mathrm{As}_{\mathrm{T}}$

TABLE 1 | Distribution of groundwater hydrogeochemical parameters within all sites, HMHA sites, and HMLA sites.

\begin{tabular}{|c|c|c|c|}
\hline Parameter & All $(n=51)$ & HMHA $(n=35)$ & HMLA $(n=16)$ \\
\hline $\mathrm{Mn}_{\mathrm{T}}\left(\mathrm{mg} \mathrm{L}^{-1}\right)$ & $\begin{array}{l}0.92 \pm 0.20 \\
(0.03-4.2)\end{array}$ & $\begin{array}{l}0.83 \pm 0.14 \\
(0.13-2.2)\end{array}$ & $\begin{array}{c}1.1 \pm 0.29 \\
(0.03-4.2)\end{array}$ \\
\hline $\mathrm{As} T\left(\mu g \mathrm{~L}^{-1}\right)$ & $\begin{array}{c}229 \pm 90 \\
(0.26-1,264)\end{array}$ & $\begin{array}{c}330 \pm 97 \\
(0.88-1,264)\end{array}$ & $\begin{array}{c}9.0 \pm 2.1 \\
(0.26-25)\end{array}$ \\
\hline $\mathrm{Fe}_{\mathrm{T}}\left(\mathrm{mg} \mathrm{L}^{-1}\right)$ & $\begin{array}{l}2.6 \pm 0.88 \\
(0.0-14)\end{array}$ & $\begin{array}{l}3.6 \pm 0.93 \\
(0.01-14)\end{array}$ & $\begin{array}{c}0.31 \pm 0.10 \\
(0.0-1.0)\end{array}$ \\
\hline $\mathrm{NO}_{3}^{-}\left(\mathrm{mg} \mathrm{L}^{-1}\right)$ & $\begin{array}{c}1.0 \pm 0.92 \\
(0.0-21)\end{array}$ & $\begin{array}{l}0.21 \pm 0.30 \\
(0.0-0.99)\end{array}$ & $\begin{array}{l}2.8 \pm 3.0 \\
(0.0-21)\end{array}$ \\
\hline $\mathrm{SO}_{4}^{2-}\left(\mathrm{mg} \mathrm{L}^{-1}\right)$ & $\begin{array}{l}8.4 \pm 3.5 \\
(0.0-52)\end{array}$ & $\begin{array}{l}5.0 \pm 2.8 \\
(0.0-35)\end{array}$ & $\begin{array}{l}16 \pm 9.7 \\
(0.0-52)\end{array}$ \\
\hline $\mathrm{DOC}\left(\mathrm{mg} \mathrm{L}^{-1}\right)$ & $\begin{array}{c}1.7 \pm 0.16 \\
(0.58-3.3)\end{array}$ & $\begin{array}{c}1.8 \pm 0.15 \\
(0.58-3.3)\end{array}$ & $\begin{array}{c}1.3 \pm 0.13 \\
(0.62-2.3)\end{array}$ \\
\hline $\operatorname{TDN}\left(\mathrm{mg} \mathrm{L}^{-1}\right)$ & $\begin{array}{l}3.8 \pm 1.3 \\
(0.0-24)\end{array}$ & $\begin{array}{l}4.0 \pm 1.4 \\
(0.0-15)\end{array}$ & $\begin{array}{c}3.3 \pm 3.7 \\
(0.13-24)\end{array}$ \\
\hline$E_{h}(m V)$ & $\begin{array}{c}+207 \pm 34 \\
(+99-(+) 363)\end{array}$ & $\begin{array}{c}+163 \pm 26 \\
(+99-(+) 276)\end{array}$ & $\begin{array}{c}+285 \pm 47 \\
(+151-(+) 363)\end{array}$ \\
\hline $\mathrm{pH}$ & $\begin{array}{l}7.3 \pm 0.12 \\
(6.5-8.3)\end{array}$ & $\begin{array}{l}7.3 \pm 0.13 \\
(6.5-7.8)\end{array}$ & $\begin{array}{l}7.4 \pm 0.30 \\
(6.8-8.3)\end{array}$ \\
\hline $\begin{array}{l}\text { Alkalinity }\left(\mathrm{mg} \mathrm{L}^{-1}\right. \\
\left.\text { as } \mathrm{CaCO}_{3}\right)\end{array}$ & $\begin{array}{c}399 \pm 29 \\
(148-648)\end{array}$ & $\begin{array}{c}415 \pm 30 \\
(270-648)\end{array}$ & $\begin{array}{c}357 \pm 64 \\
(148-560)\end{array}$ \\
\hline Well Depth (m) & $(8.0-43)$ & $(12-40)$ & $(8.0-43)$ \\
\hline
\end{tabular}

HMHA, High Mn, High As; HMLA, High Mn, Low As. Upper values indicate $95 \%$ confidence interval; Values in parentheses denote ranges. Shaded cells indicate statistically significant differences between HMHA and HMLA sites for that parameter $(p<0.05)$. $E_{h}, p H$, and alkalinity values are based on $n=23,45$, and 47 (of 51 total), $n=14,34$, and 35 (of 35 HMHA), and $n=9,13$, and 13 (of 16 HMLA), respectively. Well depth values represent ranges among the respective sites. 
concentrations $\left(3.4 \pm 0.26 \mu \mathrm{g} \mathrm{L}^{-1}\right)$ and is therefore discussed as an HMLA site.

Based on Visual MINTEQ speciation modeling, the dominant species of $\mathrm{Mn}$ in all studied sites was $\mathrm{Mn}^{2+}\left(\sim 73-89 \%\right.$ of $\left.\mathrm{Mn}_{\mathrm{T}}\right)$, with $\mathrm{MnHCO}_{3}^{+}$and $\mathrm{MnCO}_{3(\mathrm{aq})}$ comprising the remaining 4$17 \%$ and $\sim 7-9 \%$ of $\mathrm{Mn}_{\mathrm{T}}$, respectively (Figure S4A). There was no significant difference in the percentages of $\mathrm{Mn}^{2+}, \mathrm{MnHCO}_{3}^{+}$, and $\mathrm{MnCO}_{3(\mathrm{aq})}$ between the HMHA $\left(\mathrm{Mn}^{2+}=81.6 \pm 2.78 \%\right.$; $\left.\mathrm{MnHCO}_{3}^{+}=7.52 \pm 0.60 \% ; \mathrm{MnCO}_{3(\mathrm{aq})}=10.7 \pm 2.66 \%\right)$ and HMLA $\left(\mathrm{Mn}^{2+}=83.3 \pm 4.90 \% ; \mathrm{MnHCO}_{3}^{+}=7.42 \pm 1.05 \%\right.$; $\mathrm{MnCO}_{3(\mathrm{aq})}=9.03 \pm 4.04 \%$ ) sites (Table S4A), and all dissolved $\mathrm{Mn}$ species were of the oxidation state $\mathrm{Mn}(\mathrm{II})$. Iron speciation was more variable, with the dominant species being $\mathrm{Fe}^{2+}(\sim 30-$ $95 \%$ of $\left.\mathrm{Fe}_{\mathrm{T}}\right), \mathrm{Fe}(\mathrm{OH})_{2}^{+}\left(\sim 0-67 \%\right.$ of $\left.\mathrm{Fe}_{\mathrm{T}}\right), \mathrm{FeHCO}_{3}^{+}(\sim 2-7 \%$ of $\left.\mathrm{Fe}_{\mathrm{T}}\right)$, and $\mathrm{FeOH}^{+}\left(\sim 0-1 \%\right.$ of $\left.\mathrm{Fe}_{\mathrm{T}}\right)$ (Figure S4B). Thus, $\mathrm{Fe}(\mathrm{II})$ and $\mathrm{Fe}(\mathrm{III})$ were present in proportions of $\sim 32-99 \%$ and $0-67 \%$ of $\mathrm{Fe}_{\mathrm{T}}$, respectively. There was significantly more $\mathrm{Fe}^{2+}$ in HMHA $\left(87.4 \pm 6.31 \%\right.$ of $\left.\mathrm{Fe}_{\mathrm{T}}\right)$ than in HMLA $\left(49.9 \pm 19.9 \%\right.$ of $\left.\mathrm{Fe}_{\mathrm{T}}\right)$ sites, and there was significantly less $\mathrm{Fe}(\mathrm{OH})_{2}^{+}$(the only dominant $\mathrm{Fe}$ (III) species) in HMHA $\left(6.87 \pm 6.48 \%\right.$ of $\left.\mathrm{Fe}_{\mathrm{T}}\right)$ relative to HMLA $\left(46.2 \pm 21.7 \%\right.$ of $\left.\mathrm{Fe}_{\mathrm{T}}\right)$ sites (Table S4B). Percentages of $\mathrm{FeHCO}_{3}^{+}$were not significantly different between HMHA (5.16 $\pm 0.48 \%$ of $\left.\mathrm{Fe}_{\mathrm{T}}\right)$ and HMLA sites $\left(3.23 \pm 1.79 \%\right.$ of $\mathrm{Fe}_{\mathrm{T}}$ ) (Table S4B). Analytically determined As speciation by a previous study of these same sites demonstrated that $55-98 \%$ of $\mathrm{As}_{\mathrm{T}}$ was $\mathrm{As}$ (III) in HMHA sites, whereas the only sample analyzed from HMLA sites was $36 \%$ As(III) (Sankar et al., 2014).

Physical parameters (e.g., $\mathrm{pH}, \mathrm{E}_{\mathrm{h}}$, alkalinity, depth) were not significantly different between HMHA and HMLA sites, excluding $\mathrm{E}_{\mathrm{h}}$, which was significantly lower in HMHA (+163 $\pm 26 \mathrm{mV})$ relative to HMLA $(+285 \pm 47 \mathrm{mV})$ sites (Table 1). Correlations of physical parameters with $\mathrm{Mn}_{\mathrm{T}}, \mathrm{As}_{\mathrm{T}}$, and $\mathrm{Fe}_{\mathrm{T}}$ are presented in Tables S1-S3. A weak positive correlation was observed between $\mathrm{Mn}_{\mathrm{T}}$ and $\mathrm{As}_{\mathrm{T}}$ in HMHA groundwater, however, a significant positive correlation between $\mathrm{Mn}_{\mathrm{T}}$ and $\mathrm{As}_{\mathrm{T}}$ in Naoda was observed (Figure S2, Tables S1, S2). At Hariharpara, a positive correlation between $\mathrm{Fe}_{\mathrm{T}}$ and $\mathrm{As}_{\mathrm{T}}$ was apparent (Figure S2, Tables S2, S3). In all HMLA sites, $\mathrm{As}_{\mathrm{T}}$ and $\mathrm{Fe}_{\mathrm{T}}$ were positively correlated (Figure S2, Tables S2, S3). Positive correlations between $\mathrm{Mn}_{\mathrm{T}}$ and $\mathrm{As}_{\mathrm{T}}$ and between $\mathrm{As}_{\mathrm{T}}$ and $\mathrm{Fe}_{\mathrm{T}}$ were observed in groundwater from the Nabagram location (Tables S1-S3).

\section{Dissolved Organic Matter Quality}

Dissolved organic carbon (DOC) concentrations at the HMHA sites $\left(1.8 \pm 0.15 \mathrm{mg} \mathrm{L}^{-1}\right)$ were significantly higher than at HMLA sites $\left(1.3 \pm 0.13 \mathrm{mg} \mathrm{L}^{-1}\right)$. Total dissolved nitrogen concentrations (TDN) at HMHA sites $\left(4.0 \pm 1.4 \mathrm{mg} \mathrm{L}^{-1}\right)$ and HMLA sites $\left(3.3 \pm 3.7 \mathrm{mg} \mathrm{L}^{-1}\right)$ were not significantly different (Table 1). At the HMHA sites, groundwater DOC was positively correlated with $\mathrm{Mn}_{\mathrm{T}}$ (Figure S2, Table S1) and also with $\mathrm{As}_{\mathrm{T}}$ (Figure S2, Table S2), but not with $\mathrm{Fe}_{\mathrm{T}}$ (Figure S2, Table S3). By contrast, in HMLA groundwater, no significant correlation of DOC with $\mathrm{Mn}_{\mathrm{T}}, \mathrm{As}_{\mathrm{T}}$ or $\mathrm{Fe}_{\mathrm{T}}$ (Figure S2, Tables S1-S3) was found. Isolating just Kandi samples revealed a significant positive correlation between $\mathrm{Mn}_{\mathrm{T}}$ and DOC concentrations, however (Table S1).

Absorbance at $254 \mathrm{~nm}\left(\mathrm{Abs}_{254}\right)$ intensities for groundwater from the HMHA sites $(0.047 \pm 0.006)$ were significantly higher than for groundwater from the HMLA sites (0.029 \pm 0.007$)$ (Table 2). Specific ultraviolet absorbance at $254 \mathrm{~nm}\left(\mathrm{SUVA}_{254}\right)$ values at HMHA sites $\left(2.60 \pm 0.28 \mathrm{~L} \mathrm{mg}^{-1} \mathrm{~m}^{-1}\right)$ and HMLA sites $\left(2.43 \pm 0.39 \mathrm{~L} \mathrm{mg}^{-1} \mathrm{~m}^{-1}\right)$ did not vary significantly (Table 2$)$. It should be noted that ferric iron concentrations can artificially enhance $\mathrm{Abs}_{254}$ and $\mathrm{SUVA}_{254}$ values due to similar absorbance spectra (Weishaar et al., 2003), and that the variability of $\mathrm{Fe}_{\mathrm{T}}$ concentrations between HMHA and HMLA sites (Table 1) may influence the observed variability in $\mathrm{Abs}_{254}$ (Table 2); therefore, SUVA results should be interpreted with caution. Spectral slope ratios $\left(\mathrm{S}_{\mathrm{R}}\right)$ at HMHA sites $(1.16 \pm 0.11)$ and HMLA sites $(1.44$ \pm 0.29 ) were not significantly different (Table 2 ). Within HMLA groundwater, significant positive correlations were observed between $\mathrm{SUVA}_{254}$ and $\mathrm{As}_{\mathrm{T}}$ (Table S2) and $\mathrm{SUVA}_{254}$ and $\mathrm{Fe}_{\mathrm{T}}$ (Table S3). SUVA 254 was also positively correlated with $\mathrm{As}_{\mathrm{T}}$ (Table S2) and $\mathrm{Mn}_{\mathrm{T}}$ (Table S1) in groundwater from Nabagram. In Beldanga, only $\mathrm{As}_{\mathrm{T}}$ exhibited a positive correlation with SUVA $_{254}$ (Table S2).

TABLE 2 | Distribution of groundwater dissolved organic matter parameters within all sites, HMHA sites, and HMLA sites.

\begin{tabular}{|c|c|c|c|}
\hline Parameter & All $(n=51)$ & HMHA $(n=35)$ & HMLA $(n=16)$ \\
\hline $\mathrm{Abs}_{254}$ (a.u.) & $\begin{array}{c}0.041 \pm 0.005 \\
(0.007-0.097)\end{array}$ & $\begin{array}{c}0.047 \pm 0.006 \\
(0.014-0.097)\end{array}$ & $\begin{array}{c}0.029 \pm 0.007 \\
(0.007-0.051)\end{array}$ \\
\hline$S_{R}$ & $\begin{array}{c}1.25 \pm 0.12 \\
(0.54-2.54)\end{array}$ & $\begin{array}{c}1.16 \pm 0.11 \\
(0.65-2.15)\end{array}$ & $\begin{array}{l}1.44 \pm 0.29 \\
(0.54-2.54)\end{array}$ \\
\hline $\begin{array}{l}\operatorname{SUVA}_{254}(\mathrm{~L} \\
\left.\mathrm{mg}^{-1} \mathrm{~m}^{-1}\right)\end{array}$ & $\begin{array}{c}2.53 \pm 0.29 \\
(0.37-4.73)\end{array}$ & $\begin{array}{c}2.60 \pm 0.23 \\
(0.96-4.27)\end{array}$ & $\begin{array}{c}2.43 \pm 0.39 \\
(0.37-4.73)\end{array}$ \\
\hline $\mathrm{FI}$ & $\begin{array}{c}1.72 \pm 0.02 \\
(1.47-1.93)\end{array}$ & $\begin{array}{c}1.72 \pm 0.02 \\
(1.53-1.89)\end{array}$ & $\begin{array}{c}1.72 \pm 0.04 \\
(1.47-1.93)\end{array}$ \\
\hline$\beta: \alpha$ & $\begin{array}{c}0.79 \pm 0.04 \\
(0.63-1.20)\end{array}$ & $\begin{array}{c}0.73 \pm 0.01 \\
(0.63-0.88)\end{array}$ & $\begin{array}{c}0.93 \pm 0.04 \\
(0.66-1.20)\end{array}$ \\
\hline HIX & $\begin{array}{c}9.30 \pm 1.62 \\
(1.87-30.24)\end{array}$ & $\begin{array}{c}11.1 \pm 1.63 \\
(1.87-30.24)\end{array}$ & $\begin{array}{c}5.32 \pm 0.89 \\
(2.19-13.46)\end{array}$ \\
\hline C1 (\%) & $\begin{array}{c}43.3 \pm 2.71 \\
(20.0-56.2)\end{array}$ & $\begin{array}{l}47.9 \pm 1.01 \\
(41.4-56.2)\end{array}$ & $\begin{array}{c}33.1 \pm 3.13 \\
(20.0-50.6)\end{array}$ \\
\hline C2 (\%) & $\begin{array}{l}36.6 \pm 1.68 \\
(21.0-55.0)\end{array}$ & $\begin{array}{c}37.5 \pm 0.94 \\
(30.0-43.2)\end{array}$ & $\begin{array}{l}34.7 \pm 2.57 \\
(21.0-55.0)\end{array}$ \\
\hline C3 (\%) & $\begin{array}{c}9.91 \pm 1.14 \\
(0.00-22.0)\end{array}$ & $\begin{array}{c}9.09 \pm 1.04 \\
(4.15-22.0)\end{array}$ & $\begin{array}{c}11.7 \pm 1.17 \\
(0.00-18.1)\end{array}$ \\
\hline C4 (\%) & $\begin{array}{c}10.2 \pm 3.44 \\
(0.00-47.6)\end{array}$ & $\begin{array}{c}5.47 \pm 1.39 \\
(0.00-17.7)\end{array}$ & $\begin{array}{c}20.5 \pm 4.67 \\
(0.00-47.6)\end{array}$ \\
\hline Humic:Protein & $\begin{array}{c}10.3 \pm 1.12 \\
(3.54-23.1)\end{array}$ & $\begin{array}{c}11.5 \pm 1.12 \\
(3.54-23.1)\end{array}$ & $\begin{array}{c}7.56 \pm 0.64 \\
(4.54-11.9)\end{array}$ \\
\hline Terr:Microb & $\begin{array}{c}5.84 \pm 0.91 \\
(0.73-14.7)\end{array}$ & $\begin{array}{c}6.74 \pm 0.76 \\
(3.07-14.7)\end{array}$ & $\begin{array}{c}3.62 \pm 0.97 \\
(0.73-11.7)\end{array}$ \\
\hline
\end{tabular}

${ }^{\mathrm{C} 1}$ Terrestrial, humic-like; ${ }^{\mathrm{C} 2}$ Humic-like, impacted by agriculture, marine humic; ${ }^{C 3}$ Proteinlike, tyrosine and tryptophan; ${ }^{C 4}$ Microbial humic-like (Kulkarni et al., 2016). HMHA, High Mn, High As; HMLA, High Mn, Low As. Upper values indicate $95 \%$ confidence interval; Values in parentheses denote ranges. Shaded cells indicate statistically significant differences between HMHA and HMLA sites for that parameter $(p<0.05)$. 

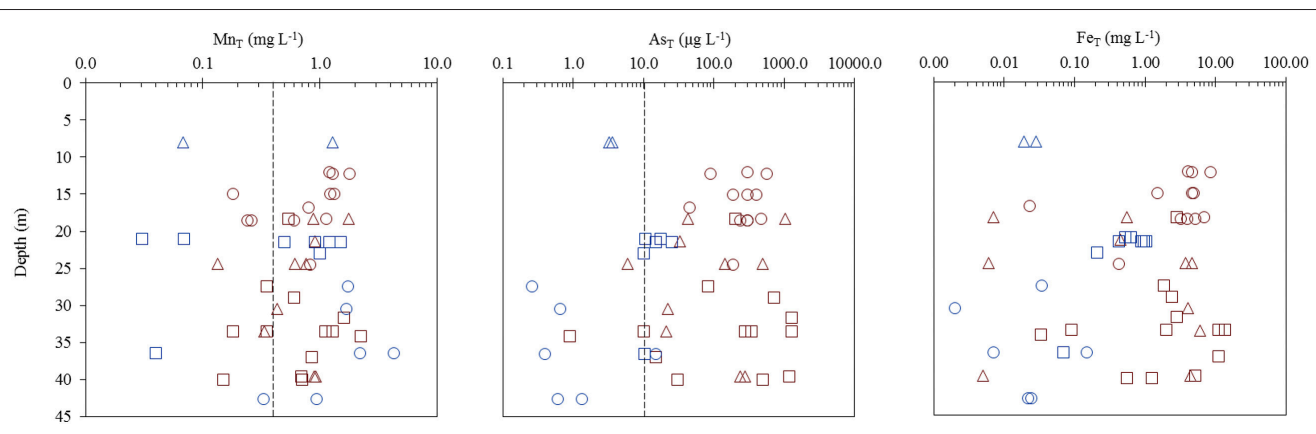

FIGURE 2 | Vertical distribution of dissolved $\mathrm{Mn}_{\mathrm{T}}$, AsT, and Fe for Beldanga ( $\square$ ), Hariharpara (O), Naoda $(\Delta)$ ), Kandi $(\square)$, Nabagram (O), and Khidirpur ( $\Delta$ ). Dotted lines represent WHO limits for $\mathrm{Mn}\left(0.4 \mathrm{mg} \mathrm{L}^{-1}-\right.$ Revoked in 2011) and As $(10 \mu \mathrm{g} \mathrm{L}-1)$.

Fluorescence index (FI), freshness index $(\beta: \alpha)$ and humification index (HIX) at HMHA sites were $1.72 \pm 0.02$, $0.73 \pm 0.01$, and $11.1 \pm 1.63$, respectively, whereas they were $1.72 \pm 0.04,0.93 \pm 0.04$, and $5.32 \pm 0.89$, respectively, at the HMLA sites (Table 2). Fluorescence index (FI) did not vary significantly between HMHA and HMLA groundwater, whereas $\beta: \alpha$ was significantly lower in HMHA groundwater than in HMLA groundwater, and HIX was significantly higher in HMHA groundwater than in HMLA (Table 2).

A negative correlation was observed in all sites between $\mathrm{As}_{\mathrm{T}}$ and $\beta: \alpha$ (Table S2) and between $\mathrm{Fe}_{\mathrm{T}}$ and $\beta: \alpha$ (Table S3), whereas a positive correlation was observed between $\mathrm{As}_{\mathrm{T}}$ and HIX (Table S2). At the HMLA sites, a negative correlation was found between $\mathrm{Mn}_{\mathrm{T}}$ and $\beta: \alpha$ (Table S1), whereas $\mathrm{As}_{\mathrm{T}}$ and $\mathrm{Fe}_{\mathrm{T}}$ were positively correlated with $\beta: \alpha$ (Tables S2, S3). In Nabagram, $\mathrm{As}_{\mathrm{T}}$ was negatively correlated with $\beta: \alpha$ (Table S2). A positive correlation was observed between FI and $\mathrm{Fe}_{\mathrm{T}}$ in Naoda (Table S3), and in Beldanga FI was negatively correlated with $A s_{T}$, and $A s_{T}$ with $\beta: \alpha$ (Table S2).

The PARAFAC model identified 4 fluorescence components (Table 2, Figure 3, Table S5): (1) a terrestrial humic-like (C1) component; (2) a humic-like component influenced by agricultural and wastewater activities (C2); (3) a protein-like component similar to tryptophan and tyrosine (C3); and (4) a microbial humic-like (C4) component. The four components identified were similar to components $\mathrm{C} 1-\mathrm{C} 4$ found in an earlier study in this region (Kulkarni et al., 2016). On average, the \% $\mathrm{C} 1$ in groundwater from the HMHA sites $(47.9 \% \pm 1.01)$ was significantly higher than \% $\mathrm{C} 1$ in groundwater from the HMLA sites $(33.1 \% \pm 3.13)$ (Table 2). In all sites and within HMLA sites, \% $\mathrm{C} 1$ was positively correlated with $\mathrm{As}_{\mathrm{T}}$ concentrations (Table S2), and also with $\mathrm{Fe}_{\mathrm{T}}$ concentrations at HMLA sites (Table S3). The component \% C2 in groundwater from the HMHA sites $(37.5 \% \pm 0.94)$ and at the HMLA sites $(34.7 \%$ \pm 2.57 ) was not significantly different (Table 2). Groundwater from HMLA sites shows positive correlations between \% C2 and $\mathrm{As}_{\mathrm{T}}$ (Table S2) and with $\mathrm{Fe}_{\mathrm{T}}$ (Table S3). Component C3 (\%) was significantly higher in groundwater from the HMLA sites $(11.7 \% \pm 1.17)$ than in groundwater from the HMHA sites $(9.09 \% \pm 1.04)$ (Table 2). Positive correlations between $\mathrm{As}_{\mathrm{T}}$ and
$\%$ C3 at all sampled locations (Table S2) and between $\mathrm{As}_{\mathrm{T}}$ and $\% \mathrm{C} 3$ at Beldanga (Table S2) were observed. The proportion of the DOM pool attributed to Component C4 (\% C4) was significantly higher in groundwater from the HMLA sites $(20.5 \%$ $\pm 4.67)$ than in groundwater from the HMHA sites $(5.47 \% \pm$ 1.39) (Table 2). A positive correlation between $\mathrm{As}_{\mathrm{T}}$ and \% $\mathrm{C} 4$ in groundwater from the HMLA sites was observed (Table S2). No significant correlations were observed between $\mathrm{Mn}_{\mathrm{T}}$ and any of the proportions of the total DOM pool (Table S1).

\section{Bulk Sediment Geochemistry}

Bulk sediment concentrations of $\mathrm{Mn}\left(278 \pm 67.5 \mathrm{mg} \mathrm{kg}^{-1}\right)$, As $\left(6.61 \pm 1.84 \mathrm{mg} \mathrm{kg}^{-1}\right)$ and $\mathrm{Fe}\left(21.9 \pm 4.82 \mathrm{~g} \mathrm{~kg}^{-1}\right)$ at the HMHA sites were not significantly different than Mn (420 $\left.\pm 122 \mathrm{mg} \mathrm{kg}^{-1}\right)$, As $\left(4.72 \pm 0.36 \mathrm{mg} \mathrm{kg}^{-1}\right)$ and $\mathrm{Fe}(19.2 \pm$ $3.24 \mathrm{~g} \mathrm{~kg}^{-1}$ ) contents of the sediments from the HMLA sites (Table 3, Figure 4). Bulk As and Fe contents of sediments were positively correlated within all sites, within HMHA sites, and at Hariharpara (Table S4, Figure S3). Sediment Mn and Fe concentrations were positively correlated within the HMHA sites, at Hariharpara, and at Beldanga (Table S4, Figure S3). Similarly, sedimentary $\mathrm{Mn}$ and As were positively correlated at Hariharpara (Table S4, Figure S3).

\section{DISCUSSION}

The distribution of dissolved $\mathrm{Mn}_{\mathrm{T}}$ and $\mathrm{As}_{\mathrm{T}}$ in groundwater of this study area appears to be controlled by redox processes as has been noted in previous studies in other regions of the Bengal Basin (Bhattacharya et al., 2002; McArthur et al., 2004, 2008; Buschmann et al., 2007; von Brömssen et al., 2007; Sankar et al., 2014). Elevated $\mathrm{Mn}_{\mathrm{T}}$ was prevalent throughout all surveyed sites, yet $\mathrm{As}_{\mathrm{T}}$ and $\mathrm{Fe}_{\mathrm{T}}$ were constrained to groundwater with lower $\mathrm{E}_{\mathrm{h}}$ and dissolved $\mathrm{NO}_{3}^{-}$concentrations. Greater quantities of DOC and humic-like, terrestrial DOM coincided with low $\mathrm{E}_{\mathrm{h}}$, high $\mathrm{As}_{\mathrm{T}}$ and $\mathrm{Fe}_{\mathrm{T}}$ groundwater. By contrast, lower DOC concentrations and protein-like DOM were present within high $\mathrm{E}_{\mathrm{h}}$ and low $\mathrm{As}_{\mathrm{T}}$ and $\mathrm{Fe}_{\mathrm{T}}$ groundwater. The distribution of $\mathrm{Mn}_{\mathrm{T}}$ was seemingly unaffected by both DOC quantity and DOM quality, as $\mathrm{Mn}_{\mathrm{T}}$ concentrations were consistently high. It should be noted here that $E_{h}$ is employed as a qualitative measure of the general redox 

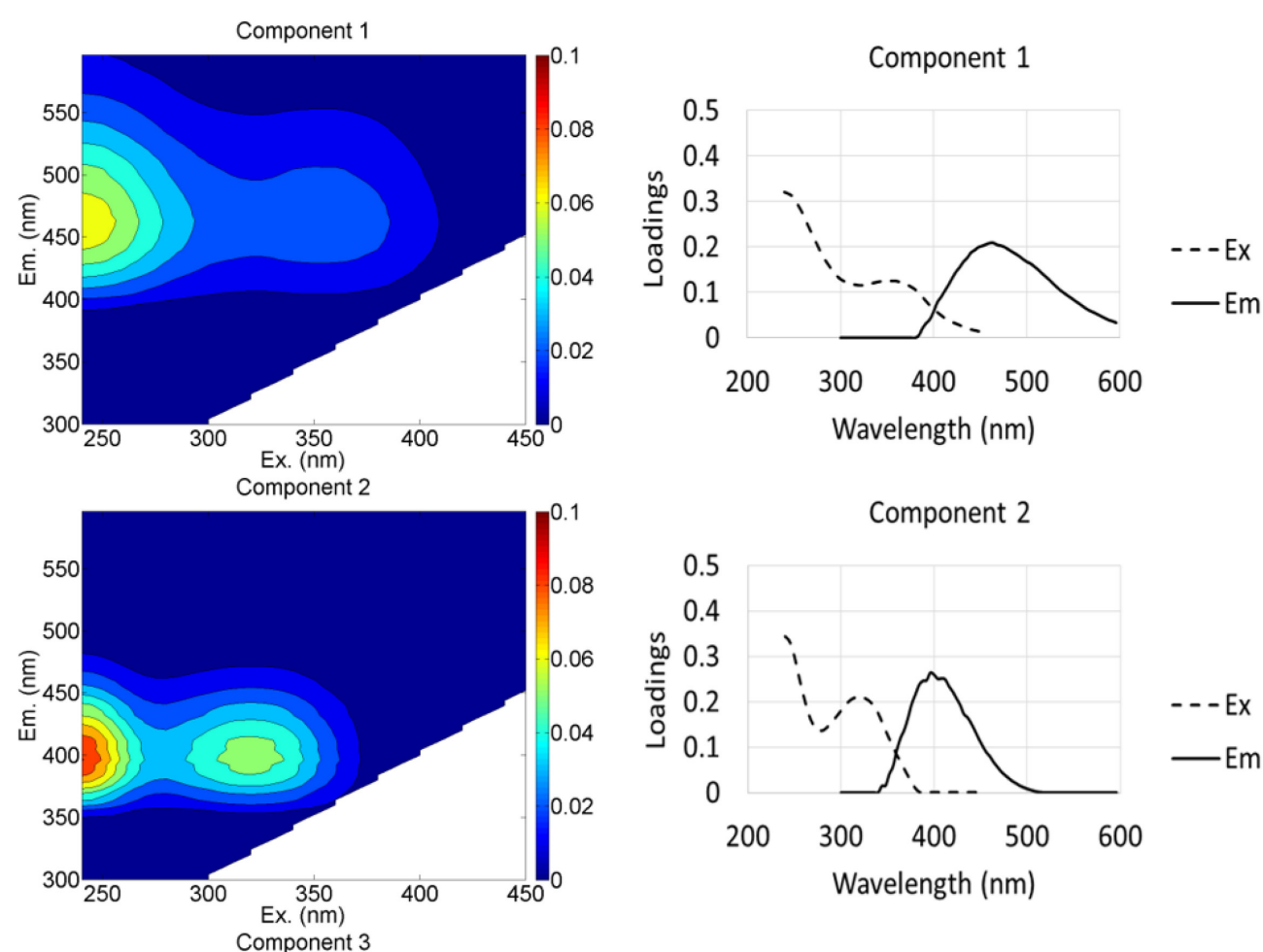

Component 2
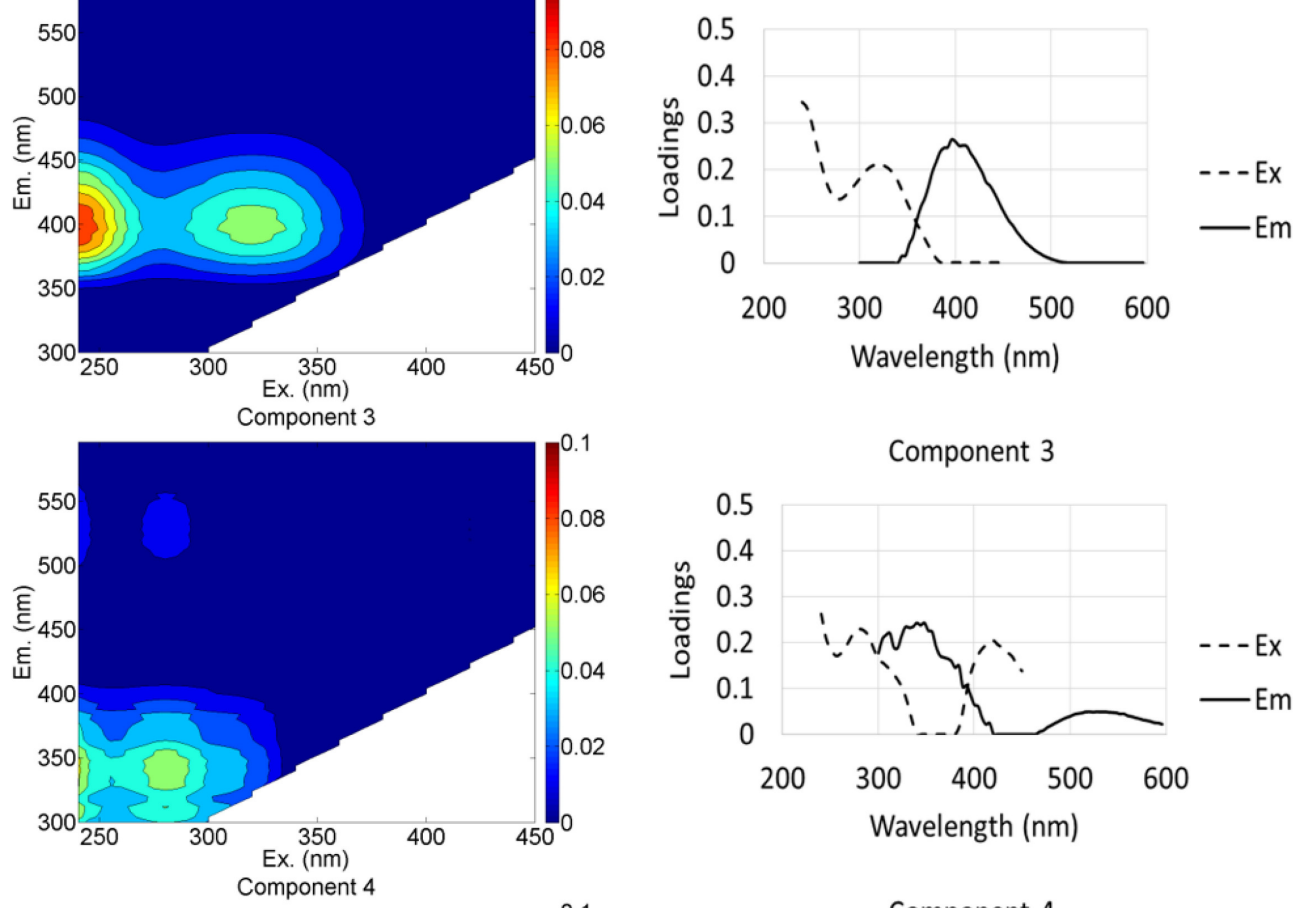

Component 3
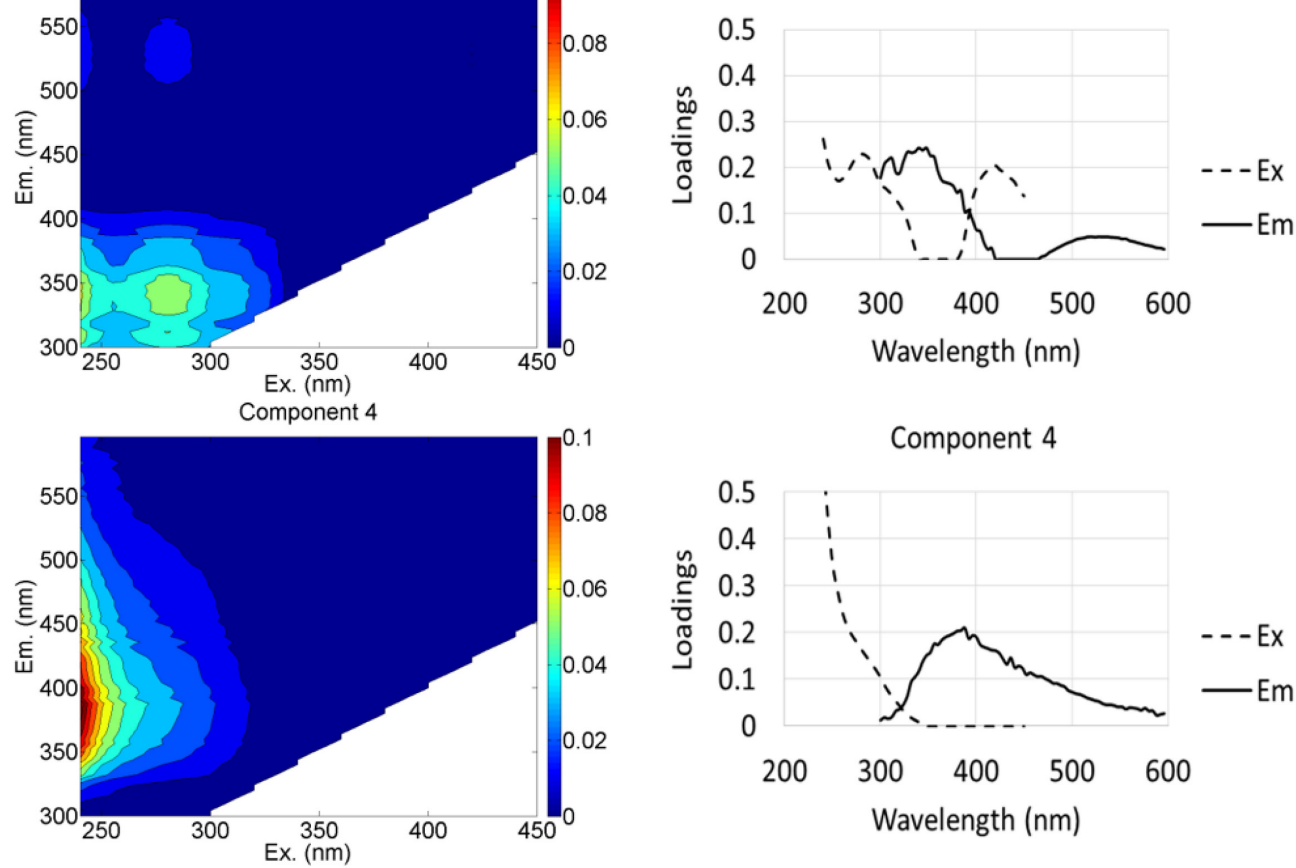

FIGURE 3 | EEM spectra (left) and emission-excitation curves (right) showing loadings of four PARAFAC components identified in the model.

state of groundwater, as it is a difficult parameter to quantify due to the inherent redox disequilibrium in natural waters (Lindberg and Runnells, 1984; Stefansson et al., 2005). The discussions herein will attempt to correlate the release and accumulation of $\mathrm{Mn}$, As, and Fe species with redox chemistry, carbonate chemistry and DOM properties. 

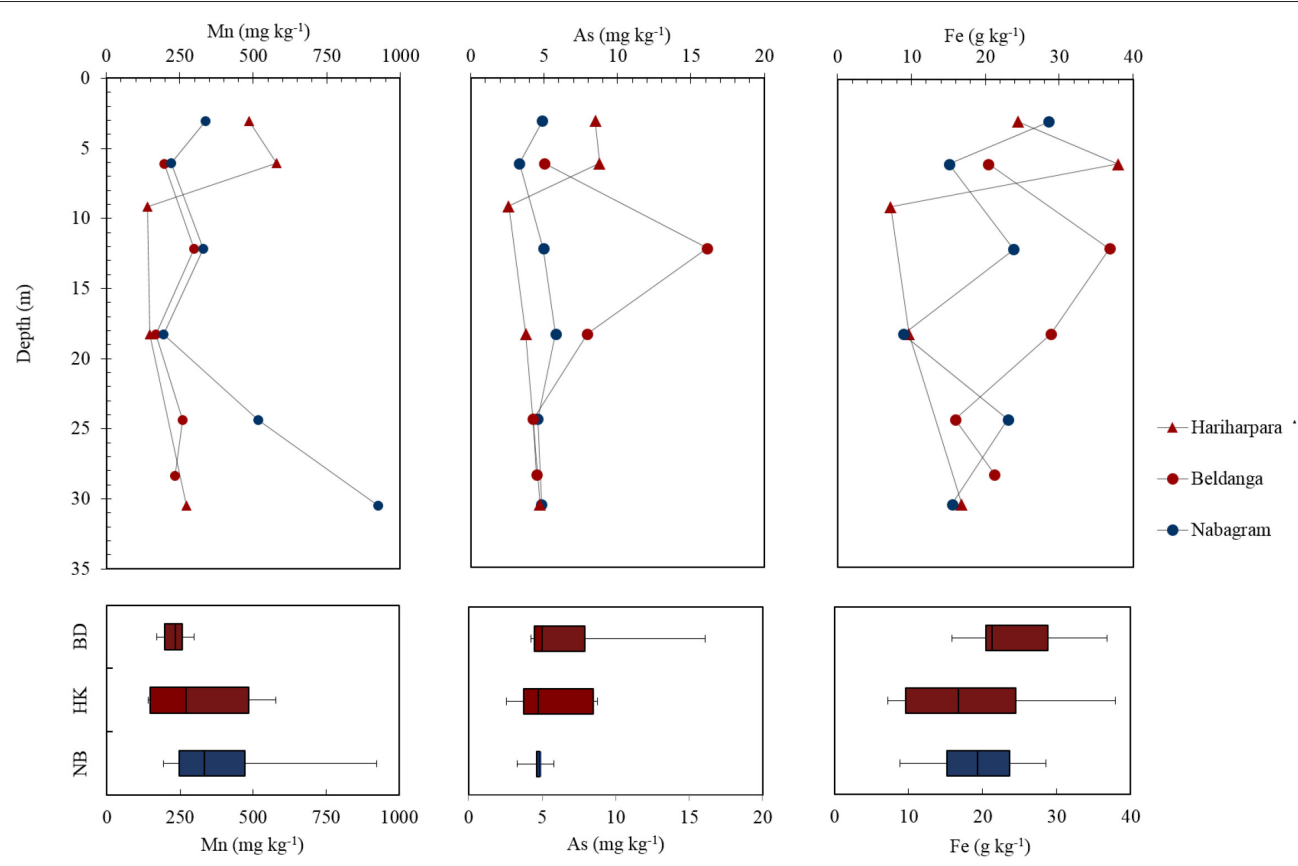

FIGURE 4 | Depth plots of bulk sediment concentrations of Mn, As, and Fe in Hariharpara ( $\mathbf{\Delta}$ ), Beldanga (•), and Nabagram (•). Box-and-whisker plots depict distribution of the elements in Nabagram (NB), Hariharpara (HK), and Beldanga (BD), respectively.

TABLE 3 | Distribution of bulk sediment concentrations of Mn, As, and Fe within all sites, HMHA sites, and HMLA sites.

\begin{tabular}{llcc}
\hline Parameter & All $(\boldsymbol{n}=\mathbf{1 6})$ & HMHA $(\boldsymbol{n}=\mathbf{1 0})$ & HMLA $(\boldsymbol{n}=\mathbf{6})$ \\
\hline $\mathrm{Mn}\left(\mathrm{mg} \mathrm{kg}^{-1}\right)$ & $331 \pm 97.6$ & $278 \pm 67.5$ & $420 \pm 122$ \\
& $(141-924)$ & $(141-578)$ & $(194-924)$ \\
As $\left(\mathrm{mg} \mathrm{kg}^{-1}\right)$ & $5.90 \pm 1.54$ & $6.61 \pm 1.84$ & $4.72 \pm 0.36$ \\
& $(2.59-16.1)$ & $(2.59-16.1)$ & $(3.31-5.78)$ \\
Fe $\left(\mathrm{g} \mathrm{kg}^{-1}\right)$ & $20.9 \pm 4.34$ & $21.9 \pm 4.82$ & $19.2 \pm 3.24$ \\
& $(7.16-38.0)$ & $(7.16-38.0)$ & $(8.87-28.6)$ \\
\hline
\end{tabular}

HMHA, High Mn, High As; HMLA, High Mn, Low As. Upper values indicate $95 \%$ confidence interval; Values in parentheses denote ranges. Absence of shaded cells indicates that no statistically significant differences between HMHA and HMLA sites were observed $(p<0.05)$.

\section{Mobilization of Mn and As from Sediments to Groundwater}

The solid phase concentrations of $\mathrm{Mn}, \mathrm{Fe}$, and As (Table 3) suggest that there are abundant metal(loid) concentrations in the shallow aquifers of Murshidabad. Hering and Kneebone (2002) experimentally showed that even $1.8 \mathrm{mg} \mathrm{kg}^{-1}$ of sedimentary As was enough to cause dissolved concentrations $>10 \mu \mathrm{g}$ $\mathrm{L}^{-1}$ under reducing conditions in the presence of sufficient labile organic carbon. Previously, we showed that both the HMHA and HMLA sites have substantial sedimentary organic matter ( $\sim 10-20 \%$ by weight) (Datta et al., 2011; Sankar, 2013; Mohajerin et al., 2014; Kulkarni et al., 2016), which could drive microbial reductive dissolution of both $\mathrm{Mn}$ and $\mathrm{Fe}$ minerals. Elevated dissolved concentrations of $\mathrm{Fe}_{\mathrm{T}}$ and $\mathrm{As}_{\mathrm{T}}$ in groundwater from other regions of the Bengal Basin have been described previously, and are thought to be the result of microbial reductive dissolution of $\mathrm{Fe}$ minerals under anoxic conditions (McArthur et al., 2001, 2004; Bhattacharya et al., 2002; Dowling et al., 2002; Roychowdhury et al., 2002; Horneman et al., 2004; Ravenscroft et al., 2005; Sankar et al., 2014). By contrast, relatively higher $\mathrm{E}_{\mathrm{h}}$ values in HMLA sites may explain lower $\mathrm{Fe}_{\mathrm{T}}(\sim 0.31 \mathrm{mg}$ $\left.\mathrm{L}^{-1}\right)$ and $\mathrm{As}_{\mathrm{T}}\left(\sim 9.0 \mu \mathrm{g} \mathrm{L}^{-1}\right)$ concentrations. The average $\mathrm{Mn}_{\mathrm{T}}$ and $\mathrm{Fe}_{\mathrm{T}}$ concentrations in groundwater from the HMHA sites were 0.83 and $3.6 \mathrm{mg} \mathrm{L}^{-1}$ (i.e., $\mathrm{Mn}_{\mathrm{T}}<\mathrm{Fe}_{\mathrm{T}}$ ), whereas HMLA groundwater had average $\mathrm{Mn}_{\mathrm{T}}$ and $\mathrm{Fe}_{\mathrm{T}}$ concentrations of 1.1 and $0.31 \mathrm{mg} \mathrm{L}^{-1}$, respectively (i.e., $\mathrm{Mn}_{\mathrm{T}}>\mathrm{Fe}_{\mathrm{T}}$ ). These observations were consistent with the stoichiometry that 1 mole of acetate (simplest electron donor) would produce 8 moles of Fe(II) but only 4 moles of Mn(II) (e.g., Lovley and Phillips, 1988). Assuming that the same organic matter was used as an electron donor for both $\mathrm{Fe}(\mathrm{III})$ and $\mathrm{Mn}(\mathrm{IV})$ reduction, groundwater from the HMHA sites was apparently reducing enough to be dominated by $\mathrm{Fe}(\mathrm{III})$ reduction, releasing greater $\mathrm{Fe}(\mathrm{II})$ than $\mathrm{Mn}$ (II). In contrast, groundwater from the HMLA sites was less reducing. This may have led to $\mathrm{Mn}(\mathrm{IV})$ reduction remaining dominant and thus greater amounts of $\mathrm{Mn}$ (II) being released to solution relative to $\mathrm{Fe}(\mathrm{II})$.

Based on thermodynamics, it is suggested that after $\mathrm{O}_{2}$ and $\mathrm{NO}_{3}^{-}$are reduced, $\mathrm{Mn}(\mathrm{IV})$ is commonly the next electron acceptor utilized by respiratory bacteria (Champ et al., 1979; Stumm and Morgan, 1981; Rittman and McCarty, 2001; McGuire et al., 2002; Bethke et al., 2011). Microbial Fe(III) reduction typically occurs after $\mathrm{Mn}(\mathrm{IV})$ is reduced. However, in natural systems, these zones are not sharply defined but rather overlap substantially [e.g., simultaneous $\mathrm{Fe}(\mathrm{III})-\mathrm{SO}_{4}^{2-}$ 
reduction or simultaneous $\mathrm{SO}_{4}^{2-}$ reduction $-\mathrm{CH}_{4}$ generation] (Chapelle and Lovley, 1992; Postma and Jakobsen, 1996; Jakobsen and Postma, 1999; Kirk et al., 2004; Bethke et al., 2011). The abundance of electron acceptors also determines the prevalence of specific redox reactions by competitive exclusion of microbial communities (Lovley and Goodwin, 1988). For example, in aquifers with abundant $\mathrm{Fe}(\mathrm{III})$ but limited $\mathrm{SO}_{4}^{2-}$, iron-reducing bacteria would outcompete $\mathrm{SO}_{4}^{2-}$ reducing bacteria by limiting the concentration of electron donor such that $\mathrm{SO}_{4}^{2-}$ reduction cannot proceed (Chapelle and Lovley, 1992; Kirk et al., 2004).

Despite consistent TDN values between HMHA and HMLA sites, our analyses show that $\mathrm{NO}_{3}^{-}$concentrations were predominantly below detection (i.e., $<0.1 \mathrm{mg} \mathrm{L}^{-1}$ ) in groundwater from the HMHA sites $\left(\sim 0.21 \mathrm{mg} \mathrm{L}^{-1} ; n=28\right)$, yet significantly higher $\left(\sim 2.8 \mathrm{mg} \mathrm{L}^{-1} ; n=13\right)$ in groundwater from the HMLA sites (also observed at Nabagram site, Sankar et al., 2014). This supports the notion that under sufficiently reducing conditions with an abundance of $\mathrm{Fe}(\mathrm{III})$ and $\mathrm{Mn}$ (IV) minerals and adequate supply of labile carbon, $\mathrm{Mn}$ (IV) and $\mathrm{Fe}(\mathrm{III})$ reduction can occur simultaneously, releasing $\mathrm{Mn}(\mathrm{II}), \mathrm{Fe}(\mathrm{II})$, and adsorbed $\mathrm{As}_{\mathrm{T}}$ into HMHA groundwater. In contrast, higher concentrations of $\mathrm{NO}_{3}^{-}$were coupled with relatively higher $\mathrm{E}_{\mathrm{h}}$, abundant $\mathrm{Mn}(\mathrm{IV})$ or $\mathrm{Fe}(\mathrm{III})$ bearing minerals and sufficient sedimentary labile carbon in HMLA sites. This may suggest that simultaneous $\mathrm{NO}_{3}^{-}$and $\mathrm{Mn}(\mathrm{IV})$ reduction maintained the electron donor capacity to such a low level that $\mathrm{Fe}(\mathrm{III})$ reduction could not proceed, resulting in high dissolved $\mathrm{Mn}$ (II) but low $\mathrm{Fe}(\mathrm{II})$ and $\mathrm{As}_{\mathrm{T}}$ concentrations. Contrasting regimes of high and low $\mathrm{As}_{\mathrm{T}}$ groundwater (i.e., as in HMHA or HMLA in this study) are widespread throughout the Bengal Basin and other fluviodeltaic plains (Buschmann et al., 2007; von Brömssen et al., 2008; Bhattacharya et al., 2009; Bundschuh et al., 2010; Hug et al., 2011).

In the HMLA sites, it is expected that Mn(IV)—oxide bound $\mathrm{As}_{\mathrm{T}}$ would accumulate in the aqueous phase upon reductive dissolution of $\mathrm{Mn}(\mathrm{IV})$-oxides; however, this is not the case in the current study. Lower $\mathrm{As}_{\mathrm{T}}$ concentrations may be attributed to the re-adsorption of $\mathrm{As}_{\mathrm{T}}$ onto clay minerals, carbonate minerals, or incompletely reduced $\mathrm{Fe}(\mathrm{III}$ )—oxides (Manning and Goldberg, 1997; McArthur et al., 2004; Guo et al., 2007; Bhattacharya et al., 2009).

The possibility that $\mathrm{PO}_{4}^{3-}$ effectively competes with $\mathrm{As}_{\mathrm{T}}$ for adsorption sites is considered negligible for groundwater from the HMLA sites because $\mathrm{PO}_{4}^{3-}$ concentrations were below detection (i.e., $<0.1 \mathrm{mg} \mathrm{L}^{-1}$; Jain and Loeppert, 2000; Dixit and Hering, 2003; Stollenwerk et al., 2007). Mn(IV)—oxides have been shown to oxidize $\mathrm{Fe}(\mathrm{II})$ even in the presence of $\mathrm{Fe}(\mathrm{III})$ reducing microorganisms (Lovley and Phillips, 1988), which could precipitate $\mathrm{Fe}(\mathrm{III})$ - oxides. This provides additional sorption sites for $\mathrm{As}_{\mathrm{T}}$ and maintains low $\mathrm{Fe}(\mathrm{II})$ and $A s_{\mathrm{T}}$ concentrations in groundwater, as was shown experimentally by $\mathrm{Wu}$ et al. (2015). Several studies have reported the oxidation of As(III) by $\mathrm{Mn}(\mathrm{IV})$ and subsequent adsorption of $\mathrm{As}(\mathrm{V})$ onto $\mathrm{Mn}$ and $\mathrm{Fe}$ bearing minerals, specifically oxides (Oscarson et al., 1981; Sun et al., 1999; Manning et al., 2002; Amirbahman et al., 2006; Stollenwerk et al., 2007; Ehlert et al., 2014, 2016; Bai et al., 2016). Hence, the higher $\mathrm{Mn}(\mathrm{II})$ and lower $\mathrm{Fe}(\mathrm{II})$ and $\mathrm{As}_{\mathrm{T}}$ concentrations in groundwater from the HMLA sites may be a product of $\mathrm{Mn}(\mathrm{IV})$ reduction and the associated oxidation of $\mathrm{Fe}(\mathrm{II})$ and $\mathrm{As}(\mathrm{III})$.

The above discussion mostly conforms to typical HMHA and HMLA sites, which are underlain by Holocene and Pleistocene sediments, respectively. A possible outlier may be the site of Khidirpur (Figure 1), a low $\mathrm{As}_{\mathrm{T}}$ yet high $\mathrm{Mn}_{\mathrm{T}}$ site, which is $\sim 2 \mathrm{~km}$ southwest of Hariharpara (HMHA site). Due to the patchy distribution of $\mathrm{As}_{\mathrm{T}}$ observed in the Bengal Basin and other fluviodeltaic plains (van Geen et al., 2003; Fendorf et al., 2010), this is not entirely surprising. In this context, one possible control could be paleointerfluvial Pleistocene deposition beneath Khidirpur (McArthur et al., 2011), which may have led to groundwater chemistry similar to other HMLA sites, overlying Pleistocene sediments. Another possible explanation could be that shallower sampling depths at Khidirpur $(\sim 8 \mathrm{~m})$ relative to nearby HMHA sites $(\sim 12-25 \mathrm{~m}$ sampling depth) were related to higher $\mathrm{E}_{\mathrm{h}}$ values observed in Khidirpur groundwater. It is possible that at $\sim 8 \mathrm{~m}$ depth, a $\mathrm{NO}_{3}^{-}-\mathrm{Mn}(\mathrm{IV})$ redox zone exists due to aeration induced by vertical mixing during the postmonsoon period. This is supported by the fact that the highest $\mathrm{NO}_{3}^{-}$concentrations (average $\sim 12 \mathrm{mg} \mathrm{L}^{-1}$ ) of all sampled wells ( $n=51)$ were observed in Khidirpur, and $\mathrm{Mn}_{\mathrm{T}}$ concentrations were also high (average $\sim 0.67 \mathrm{mg} \mathrm{L}^{-1}$ ). The effects of vertical mixing on the geochemistry of shallow groundwater $(<40$ m) from the Nadia district $(\sim 160 \mathrm{~km}$ south of the current study site) have been observed during the post-monsoon period (Majumder et al., 2016). However, further investigations with detailed sediment analyses at Khidirpur would be necessary to understand the mechanism of $\mathrm{As}_{\mathrm{T}}$ immobilization.

\section{Influence of Dissolved Organic Matter Quality on Mn and As Mobilization}

Analyses of spectral properties of fluorescent DOM suggest that the DOM in groundwater from the HMHA sites contains more humic-like (higher Humic: Protein ratio), terrestrial (higher Terrestrial: Microbial), and decomposed (lower $\beta: \alpha$ ) organic compounds compared to the DOM in groundwater from the HMLA sites. These results are in agreement with previous investigations of DOM quality in West Bengal groundwater (Kulkarni et al., 2016).

Several studies have now demonstrated the important role of humic and biologically refractory DOM in mobilizing $\mathrm{Fe}_{\mathrm{T}}$ and $\mathrm{As}_{\mathrm{T}}$ via aqueous complex formation (Sharma et al., 2010; Liu et al., 2011). Formation of complexes between metals and DOM acts to keep those constituents in solution (Gavin et al., 2001). Another important role for humic substances in Bengal Basin groundwater is the ability of quinone moieties in humic DOM to shuttle electrons between Fe-reducing bacteria and $\mathrm{Fe}$ minerals (Lovley et al., 1996, 1998; Scott et al., 1998; Jiang and Kappler, 2008; Mladenov et al., 2010, 2015). By serving as electron shuttles, humic substances have the capability to accelerate reductive dissolution of $\mathrm{Fe}$ minerals, and the electron shuttling capacity has been shown to be very high in groundwater fulvic acids isolated from the Bengal Basin. This potential electron shuttling role by humic DOM is supported by higher concentrations of 


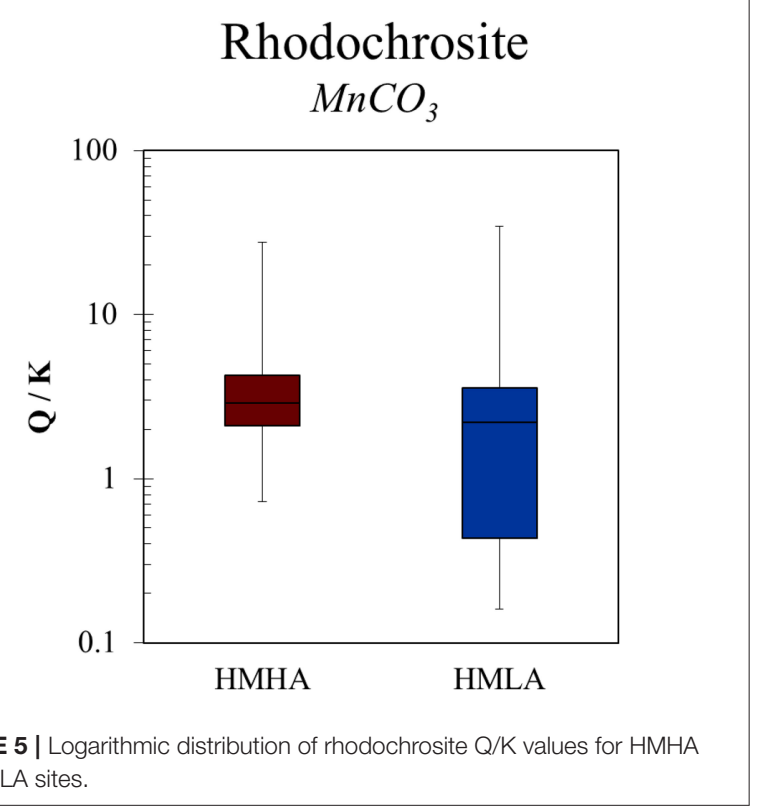

dissolved $\mathrm{Fe}_{\mathrm{T}}$ and $\mathrm{As}_{\mathrm{T}}$ in groundwater from the HMHA sites compared to groundwater from the HMLA sites. By contrast, the less aromatic and humic DOM that characterizes groundwater from the HMLA sites is expected to contribute far less to electron shuttling or complexation reactions.

Graham et al. (2002) showed that humic substances in topsoil $(0-15 \mathrm{~cm})$ formed aqueous complexes with dissolved $\mathrm{Mn}$ (II) under reducing conditions and therefore maintained higher $\mathrm{Mn}$ (II) concentrations in solution. This was partially based on humic-Mn(II) complexation inhibiting the ability for Mn precipitation reactions, as evidenced by a previous investigation (Gavin et al., 2001). In our study, because more humic-like DOM is present in groundwater from the HMHA sites relative to the HMLA sites, substantially higher $\mathrm{Mn}_{\mathrm{T}}$ concentrations could be expected in groundwater from the HMHA sites as a result of humic-Mn(II) complexation. However, saturation indices for the mineral rhodochrosite $\left(\mathrm{MnCO}_{3}\right)$ indicated supersaturation in $\sim 93 \%$ of samples from the HMHA sites (Figure 5), suggesting precipitation (Lovley and Phillips, 1988) of $\mathrm{Mn}(\mathrm{II})$ with excess $\mathrm{HCO}_{3}^{-}$that is present due to oxidation of organic matter (Ying et al., 2011). For HMLA groundwater, supersaturated conditions for rhodochrosite were observed in $63 \%$ of samples (Figure 5). Despite differences in rhodochrosite saturation calculations and $\mathrm{DOM}$ quality, $\mathrm{Mn}_{\mathrm{T}}$ concentrations were similar in groundwater from the HMHA and HMLA sites. It is possible that humic DOM-Mn(II) complexation inhibits the precipitation of rhodochrosite in HMHA groundwater, resulting in comparable concentrations of dissolved Mn between the two regions. This is contrary to the expectation that greater $\mathrm{Mn}_{\mathrm{T}}$ would be dissolved in HMHA groundwater based on: (i) humics acting as electron shuttles to catalyze $\mathrm{Mn}(\mathrm{IV})$ reduction, (ii) inherently lower $\mathrm{E}_{\mathrm{h}}$ values, and (iii) a greater abundance of DOC for heterotrophic microbial metabolisms to catalyze $\mathrm{Mn}(\mathrm{IV})$ reduction.

\section{Spatial Distribution of Dissolved Mn and As: Implications for Human Health}

This study shows concentrations of groundwater $\mathrm{Mn}_{\mathrm{T}}$ and $\mathrm{As}_{\mathrm{T}}$ far exceed their recommended health limits in drinking water. The fact that $73 \%$ of the tube wells sampled exceed the revoked WHO limit of $\mathrm{Mn}_{\mathrm{T}}$ in drinking waters of $0.4 \mathrm{mg} \mathrm{L}^{-1}$ substantiates the notion that the reimplementation of a guideline value is prudent. Geogenic $\mathrm{Mn}_{\mathrm{T}}$ contamination of groundwater is widespread throughout West Bengal, as well as in groundwater from Bangladesh, the Mekong Delta, and some parts of Europe, and recent advances in understanding its neurotoxicity are receiving attention worldwide (Wasserman et al., 2006, 2008, 2011; Barrett, 2007; Bouchard et al., 2007, 2011; Hafeman et al., 2007; Grazuleviciene et al., 2009; Ljung et al., 2009; Spangler and Spangler, 2009; Wood, 2009; Zota et al., 2009; Khan et al., 2012). Furthermore, the co-occurrence of $\mathrm{Mn}_{\mathrm{T}}$ with $\mathrm{As}_{\mathrm{T}}$ in groundwater is of particular concern, where the release of both may be linked to the dissolution of metal-oxides under reducing conditions. Although regional studies such as Buschmann et al. (2008) and McArthur et al. (2004) have documented an inverse relationship between dissolved $\mathrm{Mn}$ and As in groundwater, it is important to note that such deductions are most often applicable to basin-wide investigations. Probing these relations within a single sampling site, or a constrained series of sites as in the current study, may reveal unique trends that are heterogeneous and difficult to generalize. Effectively assessing an area for $\mathrm{Mn}_{\mathrm{T}}$ and $\mathrm{As}_{\mathrm{T}}$ contamination requires both of these perspectivesknowledge of regional and local scale relationships-in order to predict or evaluate the quality of water in a given well.

This study affirms that elevated $A s_{\mathrm{T}}$ does not exclude the possibility of elevated $\mathrm{Mn}_{\mathrm{T}}$, especially in reducing, geogenically derived systems rich in labile DOM. Likewise, elevated $\mathrm{Mn}_{\mathrm{T}}$ does not imply the absence of $\mathrm{As}_{\mathrm{T}}$. Knowledge of redox conditions, most easily attained via sediment color (Biswas et al., 2012b), can be a useful tool in estimating whether high Mn waters may be afflicted with high As concentrations. Nonetheless, it is apparent that obtaining "safe" drinking water from subsurface aquifers in Murshidabad is a serious challenge. Oxidized sediments similar to those in HMLA regions, i.e., brown sand aquifers and paleointerfluves, have been posed as alternative drinking water sources in SE Asia, however, the prevalence of dissolved $\mathrm{Mn}_{\mathrm{T}}$ in these systems has raised concerns (von Brömssen et al., 2007; McArthur et al., 2008, 2012b; Biswas et al., 2012b, 2014 and references therein). Other strategies such as filtration and rainwater have been implemented, but due to cost and maintenance their application is not practical at this time (Hossain et al., 2015). It is important that remediation strategies and alternative water sources continue to be developed so that the inhabitants of regions such as SE Asia may eventually have access to safe drinking water supplies.

\section{CONCLUSION}

Geogenic $\mathrm{Mn}_{\mathrm{T}}$ contamination in West Bengal groundwater significantly exceeds the revoked WHO guideline of $0.4 \mathrm{mg} \mathrm{L}^{-1}$, and only $6 \%$ of the surveyed tube wells met the guidelines 
for both $\mathrm{Mn}_{\mathrm{T}}$ and $\mathrm{As}_{\mathrm{T}}$. The release and accumulation of these metal(loid)s is strongly related to their redox chemistry, DOM characteristics, and the availability of electron acceptors and carbonate ligands. Relationships between $\mathrm{Mn}_{\mathrm{T}}$ and DOM quality suggest that $\mathrm{Mn}_{\mathrm{T}}$ release persists in conjunction with both protein-like and humic-like DOM, whereas dissolved $\mathrm{As}_{\mathrm{T}}$ is strongly associated with humic-like, terrestrial DOM. Where $\mathrm{E}_{\mathrm{h}}$ values are lower (e.g., $\mathrm{HMHA}$ ), $\mathrm{NO}_{3}^{-}$concentrations are negligible and $\mathrm{Mn}(\mathrm{IV})$ and $\mathrm{Fe}(\mathrm{III})$ are likely the dominant electron acceptors for microorganisms, leading to elevated $\mathrm{Mn}(\mathrm{II}), \mathrm{Fe}(\mathrm{II})$, and $\mathrm{HCO}_{3}^{-}$in the groundwater. Saturation indices of rhodochrosite imply a net sink for aqueous $\mathrm{Mn}$ (II) in HMHA sites, yet $\mathrm{Mn}_{\mathrm{T}}$ concentrations are not significantly higher than in the samples with higher $\mathrm{E}_{\mathrm{h}}$ values (e.g., HMLA), detectable $\mathrm{NO}_{3}^{-}$, and low $\mathrm{As}_{\mathrm{T}}$ and $\mathrm{Fe}_{\mathrm{T}}$. It is postulated that humic- $\mathrm{Mn}$ (II) complexation was inhibiting rhodochrosite precipitation, yet further work is required to understand these mechanisms.

\section{AUTHOR CONTRIBUTIONS}

MV and SD are the principal executors of the field work, research and preparing this manuscript; $\mathrm{MV}$ is the principle researcher in this project; $\mathrm{HK}$ and $\mathrm{NM}$ contributed to the DOM modeling and interpretation and editing the manuscript; KJ, NK, $\mathrm{PB}$ contributed in data interpretation and shaping up of the manuscript; $\mathrm{GH}$, JW, and MG contributed in data interpretation

\section{REFERENCES}

Acharya, S. K., Lahiri, S., Raymahashay, B. C., and Bhowmik, A. (2000). Arsenic toxicity of groundwater in parts of the Bengal basin in India and Bangladesh: the role of Quaternary stratigraphy and Holocene sea-level fluctuation. Environ. Geol. 39, 1127-1137. doi: 10.1007/s002540000107

Amirbahman, A., Kent, D. B., Curtis, G. P., and Davis, J. A. (2006). Kinetics of sorption and abiotic oxidation of arsenic(III) by aquifer materials. Geochim. Cosmochim. Acta 70, 533-547. doi: 10.1016/j.gca.2005.10.036

Appelo, C. A. J., and Postma, D. (2005). Geochemistry, Groundwater and Pollution, 2nd Edn. Amsterdam: A.A. Balkema Publishers. doi: 10.1201/9781439833544

Avelino, M. A., Fusao, E. F., Pedroso, J. L., Arita, J. H., Ribeiro, R. T., Pinho, R. S., et al. (2014). Inherited manganism: the "cock-walk" gait and typical neuroimaging features. J. Neuro. Sci. 341, 150-152. doi: 10.1016/j.jns.2014.03.057

Bai, Y., Yang, T., Liang, J., and Qu, J. (2016). The role of biogenic Fe-Mn oxides formed in situ for arsenic adsorption and oxidation in aquatic ecosystems. Water Res. 98, 119-127. doi: 10.1016/j.watres.2016.03.068

Barceloux, D. G. (1999). Manganese. Clin. Toxicol. 37, 293-307. doi: $10.1081 /$ clt-100102427

Barrett, J. R. (2007). Manganese and infant mortality: well water may raise death rates in Bangladesh. Environ. Health. Perspect. 115, A363. doi: 10.1289/ehp.115-a363a

Bethke, C. M., Sanford, R. A., Kirk, M. F., Jin, Q., and Flynn, T. M. (2011). The thermodynamic ladder in geomicrobiology. Am. J. Sci. 311, 183-210. doi: $10.2475 / 03.2011 .01$

BGS and DPHE (2001). Arsenic Contamination of Groundwater in Bangladesh, eds D. G. Kinniburgh and P. L. Smedley, British Geological Survey Technical Report WC/00/19. Keyworth: British Geological Survey.

Bhattacharya, P., Chatterjee, D., and Jacks, G. (1997). Occurrence of Arseniccontaminated groundwater in alluvial aquifers from delta plains, eastern India: and editing sediment analyses, GH also contributed in data interpretation of the sediment geochemistry.

\section{FUNDING}

This work has been funded by National Science Foundation Grant Proposal Numbers (1) NSF-EAR1014947 (Datta-KState) and (2) NSF EAR-1014946 (Johannesson-Tulane), and (3) Sigma Xi Grants in Aid G20141015720343 (Vega-KState).

\section{ACKNOWLEDGMENTS}

The authors would like to thank the National Science Foundation (NSF), Sigma Xi, and Kansas State University for support for field trips and project management to West Bengal. The authors would also like to thank the Department of Geology at KState for funding, as well as the Departments of Agronomy and Biology for analytical assistances. Finally, the authors are greatly indebted to the inhabitants of Murshidabad who willingly helped in the logistical aspects of field sampling throughout the field excursions, and for their understanding and continuous support for these research efforts.

\section{SUPPLEMENTARY MATERIAL}

The Supplementary Material for this article can be found online at: http://journal.frontiersin.org/article/10.3389/fenvs. 2017.00029/full\#supplementary-material

options for safe drinking water supply. Int. J. Water Resour. D. 13, 79-92. doi: 10.1080/07900629749944

Bhattacharya, P., Hasan, M. A., Sracek, O., Smith, E., Ahmed, K. M., von Brömssen, M., et al. (2009). Groundwater chemistry and arsenic mobilization in the Holocene flood plains in south-central Bangladesh. Environ. Geochem. Health 31, 23-43. doi: 10.1007/s10653-008-9230-5

Bhattacharya, P., Jacks, G., Ahmed, K. M., Routh, J., and Khan, A. A. (2002). Arsenic in groundwater of the Bengal Delta Plain Aquifers in Bangladesh. Bull. Environ. Contam. Toxicol. 69, 538-545. doi: 10.1007/s00128-002-0095-5

Biswas, A., Bhattacharya, P., Mukherjee, A., Nath, B., Alexanderson, H., Kundu, A. K., et al. (2014). Shallow hydrostratigraphy in an arsenic affected region of Bengal Basin: implication for targeting safe aquifers for drinking water supply. Sci. Total. Environ. 485-486, 12-22. doi: 10.1016/j.scitotenv.2014.03.045

Biswas, A., Nath, B., Bhattacharya, P., Halder, D., Kundu, A. K., Mandal, U., et al. (2012a). Testing tubewell platform color as a rapid screening tool for arsenic and manganese in drinking water wells. Environ. Sci. Technol. 46, 434-440. doi: 10.1021/es203058a

Biswas, A., Nath, B., Bhattacharya, P., Halder, D., Kundu, A. K., Mandal, U., et al. (2012b). Hydrogeochemical contrast between brown and grey sand aquifers in shallow depth of Bengal Basin: consequences for sustainable drinking water supply. Sci. Tot. Environ. 431, 402-412. doi: 10.1016.j.scitotenv.2012.05.031

Bouchard, M. F., Sauve, S., Barbeau, B., Legrand, M., Brodeur, M., Bouffard, T., et al. (2011). Intellectual impairment in school-age children exposed to manganese from drinking water. Environ. Health Perspect. 119, 138-143. doi: 10.1289/ehp.1002321

Bouchard, M., Mergler, D., Baldwin, M., Panisset, M., Bowler, R., and Roels, H. A. (2007). Neurobehavioral functioning after cessation of manganese exposure: a follow-up after 14 years. Am. J. Ind. Med. 50, 831-840. doi: 10.1002/ajim.20407

Bundschuh, J., Litter, M. I., and Bhattacharya, P. (2010). Targeting arsenic-safe aquifers for drinking water supplies. Environ. Geochem. Health 32, 307-315. doi: $10.1007 / \mathrm{s} 10653-010-9308-8$ 
Burdige, D. J., and Gardner, K. G. (1998). Molecular weight distribution of dissolved organic carbon in marine sediment pore waters. Mar. Chem. 62, 45-64. doi: 10.1016/S0304-4203(98)00035-8

Burdige, D. J., and Homstead, J. (1994). Fluxes of dissolved organic carbon from Chesapeake Bay sediments. Geochim. Cosmochim. Acta 58, 3407-3424. doi: 10.1016/0016-7037(94)90095-7

Bureau of Indian Standards (2012). IS 10500: 2012 Drinking Water - Specification, 2nd Revision. New Delhi: BIS.

Buschmann, J., Berg, M., Stengel, C., and Sampson, M. L. (2007). Arsenic and manganese contamination of drinking water resources in Cambodia: coincidence of risk areas with low relief topography. Environ. Sci. Tech. 41, 2146-2152. doi: 10.1021/es062056k

Buschmann, J., Berg, M., Stengel, C., Winkel, L., Sampson, M. L., Trang, P. T. K., et al. (2008). Contamination of drinking water resources in the Mekong delta floodplains: arsenic and other trace metals pose serious health risks to population. Environ. Int. 34, 756-764. doi: 10.1016/j.envint.2007.12.025

Census of India (2011). Available online at: http://www.census2011.co.in/census/ district/7-murshidabad.html

Champ, D. R., Gulens, J., and Jackson, R. E. (1979). Oxidation-reduction sequences in ground water flow systems. Can. J. Earth Sci. 16, 12-23. doi: 10.1139/e79-002

Chapelle, F. H., and Lovley, D. R. (1992). Competitive exclusion of sulfate reduction by $\mathrm{Fe}(\mathrm{III})$-reducing bacteria: a mechanism for producing discrete zones of high-iron ground water. Ground Water 30, 29-36. doi: 10.1111/j.1745-6584.1992.tb00808.x

Coble, P. G. (1996). Characterization of marine and terrestrial DOM in seawater using excitation-emission matrix spectroscopy. Mar. Chem. 51, 325-346. doi: 10.1016/0304-4203(95)00062-3

Cory, R. M., and McKnight, D. M. (2005). Fluorescence spectroscopy reveals ubiquitous presence of oxidized and reduced quinones in dissolved organic matter. Environ. Sci. Technol. 39, 8142-8149. doi: 10.1021/es0506962

Datta, S. (2015). Hydrological aspects of arsenic contamination of groundwater in eastern India. Adv. Agron. 132, 75-137. doi: 10.1016/bs.agron.2015.02.001

Datta, S., Mailloux, B., Jung, H. B., Hoque, M. A., Stute, M., Ahmed, K. M., et al. (2009). Redox trapping of arsenic during groundwater discharge in sediments from the Meghna riverbank in Bangladesh. Proc. Natl. Acad. Sci. U.S.A. 106, 16930-16935. doi: 10.1073/pnas.0908168106

Datta, S., Neal, A. W., Mohajerin, T. J., Ocheltree, T., Rosenheim, B. E., White, C. D., et al. (2011). Perennial ponds are not an important source of water or dissolved organic matter to groundwaters with high arsenic concentrations in West Bengal, India. Geophys. Res. Lett. 38, 1-5. doi: 10.1029/2011GL049301

Deschamps, E., Ciminelli, V. S. T., Weidler, P. G., and Ramos, A. Y. (2003). Arsenic sorption onto soils enriched in $\mathrm{Mn}$ and Fe minerals. Clays Clay Minerals 51, 197-204. doi: 10.1346/CCMN.2003.0510210

Dixit, S., and Hering, J. G. (2003). Comparison of $\operatorname{arsenic}(\mathrm{V})$ and $\operatorname{arsenic}(\mathrm{III})$ sorption onto iron oxide minerals: implications for arsenic mobility. Environ. Sci. Technol. 37, 4182-4189. doi: 10.1021/es030309t

Dowling, C. B., Poreda, R. J., Basu, A. R., and Peters, S. L. (2002). Geochemical study of arsenic release mechanisms in the Bengal Basin groundwater. Water. Resour. Res. 38, 12-1-12-18. doi: 10.1029/2001wr000968

Ehlert, K., Mikutta, C., and Kretzchmar, R. (2014). Impact of birnessite on arsenic and iron speciation during microbial reduction of arsenic-bearing ferrihydrite. Environ. Sci. Technol. 48, 11320-11329. doi: 10.1021/es5031323

Ehlert, K., Mikutta, C., and Kretzchmar, R. (2016). Effects of manganese oxide on arsenic reduction and leaching from contaminated floodplain soil. Environ. Sci. Technol. 50, 9251-9261. doi: 10.1021/acs.est.6b01767

Farooq, S. H., Chandrasekharam, D., Norra, S., Berner, Z., Eiche, E., Thambidurai, P., et al. (2011). Temporal variations in arsenic concentration in the groundwater of Murshidabad District, West Bengal, India. Environ. Earth Sci. 62, 223-232. doi: 10.1007/s12665-010-0516-4

Fellman, J. B., Hood, E., and Spencer, R. G. M. (2010). Fluorescence spectroscopy opens new windows into dissolved organic matter dynamics in freshwater ecosystems: a review. Limnol. Oceanogr. 55, 2452-2462. doi: $10.4319 /$ lo.2010.55.6.2452

Fendorf, S., Michael, H., and van Geen, A. (2010). Spatial and temporal variations of groundwater arsenic in south and southeast Asia. Science 328, 1123-1127. doi: $10.1126 /$ science. 1172974

Foster, A. L., Brown, G. E., and Parks, G. A. (2003). X-ray adsorption fine structure study of $\mathrm{As}(\mathrm{V})$ and $\mathrm{Se}(\mathrm{IV})$ sorption complexes on hydrous $\mathrm{Mn}$ oxides. Geochim. Cosmochim. Acta 67, 1937-1953. doi: 10.1016/S0016-7037(02) 01301-7

Frisbie, S. H., Mitchell, E. J., Dustin, H., Maynard, D. M., and Sarkar, B. (2012). World Health Organization discontinues its drinking-water guideline for manganese. Environ. Health. Perspect. 120, 775-778. doi: 10.1289/ehp.1104693

Frisbie, S. H., Mitchell, E. J., Mastera, L. J., Maynard, D. M., Yusuf, A. Z., Siddiq, M. Y., et al. (2009). Public health strategies for western Bangladesh that address arsenic, manganese, uranium, and other toxic elements in drinking water. Environ. Health Perspect. 117, 410-416. doi: 10.1289/ehp.11886

Gavin, K. G., Graham, M., Kirika, A., and Britton, A. (2001). "Manganese-humic interactions in the catchment, water and sediment of Loch Bradan, S.W. Scotland," in Understanding and Managing Organic Matter in Soils, Sediments, and Waters, eds R. S. Swift and K. M. Spark (St. Paul, MN: International Humic Substances Society), 437-443.

Golden, D. C., Chen, C. C., and Dixon, J. B. (1986). Ion exchange, thermal transformations and oxidizing properties of birnessite. Clays Clay Minerals 34 511-520. doi: 10.1346/CCMN.1986.0340503

Gounot, A. M. (1994). Microbial oxidation and reduction of manganese: consequences in groundwater and applications. FEMS Microbiol. Rev. 14, 339-349. doi: 10.1111/j.1574-6976.1994.tb00108.x

Graham, M. C., Gavin, K. G., Farmer, J. G., Kirika, A., and Britton, A. (2002). Processes controlling the retention and release of manganese in the organic rich catchment of Loch Bradan. Appl. Geochem. 17, 1061-1067. doi: 10.1016/S0883-2927(02)00012-4

Grazuleviciene, R., Nadisauskiene, R., Buinauskiene, J., and Grazulevicius, T. (2009). Effects of elevated levels of manganese and iron in drinking water on birth outcomes. Pol. J. Environ. Stud. 18, 819-825.

Guo, H., Stüben, D., and Berner, Z. (2007). Adsorption of arsenic(III) and $\operatorname{arsenic}(\mathrm{V})$ from groundwater using natural siderite as the adsorbent. J. Colloid Interface Sci. 315, 47-53. doi: 10.1016/j.jcis.2007.06.035

Hafeman, D., Factor-Litvak, P., Cheng, Z., van Geen, A., and Ahsan, H. (2007). Association between manganese exposure through drinking water and infant mortality in Bangladesh. Environ. Health Perspect. 115, 1107-1112. doi: 10.1289/ehp.10051

Hansen, A. M., Kraus, T., Pellerin, B., Fleck, J., Downing, B., and Bergamaschi, B. (2016). Optical properties of dissolved organic matter (DOM): effects of biological and photolytic degradation. Limnol. Oceanogr. 61, 1015-1032. doi: $10.1002 /$ lno. 10270

Helms, J. R., Stubbins, A., Ritchie, J. D., Minor, E. C., Kieber, D. J., and Mopper, K. (2008). Absorption spectral slopes and slope ratios as indicators of molecular weight, source, and photobleaching of chromophoric dissolved organic matter. Limnol. Oceanogr. 53, 955-969. doi: 10.4319/lo.2008.53.3.0955

Hem, J. D. (1985). "Study and interpretation of the chemical characteristics of natural water, 3rd Edn.," in US Geological Survey Water-Supply Paper 2254.

Hering, J. G., and Kneebone, P. E. (2002). "Biogeochemical controls on arsenic occurrence and mobility in water supplies," in Environmental Chemistry of Arsenic, ed W. T. Frankenberger (New York, NY: Marcel Dekker, Inc.), $183-215$.

Hoque, M. A., Burgess, W. G., Shamsudduha, M., and Ahmed, K. M. (2011). Delineating low-arsenic groundwater environments in the Bengal Aquifer System, Bangladesh. Appl. Geochem. 26, 614-623. doi: 10.1016/j.apgeochem.2011.01.018

Horneman, A., van Geen, A., Kent, D. V., Mathe, P. E., Zheng, Y., Dhar, R. K., et al. (2004). Decoupling of As and Fe release to Bangladesh groundwater under reducing conditions. Part I: evidence from sediment profiles. Geochim. Cosmochim. Acta 68, 3459-3473. doi: 10.1016/j.gca.2004.01.026

Hossain, M., Rahman, S. N., Bhattacharya, P., Jacks, G., Saha, R., and Rahman, M. (2015). Sustainability of arsenic mitigation interventions-an evaluation of different alternative safe drinking water options provided in Matlab, an arsenic hot spot in Bangladesh. Front. Environ. Sci. 3:30. doi: 10.3389/fenvs.2015. 00030

Hug, S. J., Gaertner, D., Roberts, L. C., Schirmer, M., Ruettimann, T., Rosenberg, T. M., et al. (2011). Avoiding high concentrations of arsenic, manganese, and salinity in deep tubewells in Munshiganj District, Bangladesh. Appl. Geochem. 26, 1077-1085. doi: 10.1016/j.apgeochem.2011.03.012

Jain, A., and Loeppert, R. H. (2000). Effect of competing anions on the adsorption of arsenate and arsenite by ferrihydrite. J. Environ. Qual. 29, 1422-1430. doi: $10.2134 /$ jeq2000.00472425002900050008x 
Jakobsen, R., and Postma, D. (1999). Redox zoning, rates of sulfate reduction and interactions with Fe-reduction and methanogenesis in a shallow sandy aquifer, Romo, Denmark. Geochim. Cosmochim. Acta 63, 137-151. doi: 10.1016/S0016-7037(98)00272-5

Jiang, J., and Kappler, A. (2008). Kinetics of microbial and chemical reduction of humic substances: implications for electron shuttling. Environ. Sci. Technol. 42, 3563-3569. doi: 10.1021/es7023803

Kappler, A., Benz, M., Schink, B., and Brune, A. (2004). Electron shuttling via humic acids in microbial iron(III) reduction in a freshwater sediment. FEMS Microbiol. Ecol. 47, 85-92. doi: 10.1016/S0168-6496(03)00245-9

Khan, K., Wasserman, G. A., Liu, X., Ahmed, E., Parvez, F., Slavkovich, V., et al. (2012). Manganese exposure from drinking water and children's academic achievement. J. Neurotoxicol. 33, 91-97. doi: 10.1016/j.neuro.2011.12.002

Kirk, M. F., Holm, T. R., Park, J., Jin, Q., Sanford, R. A., Fouke, B. W., et al. (2004). Bacterial sulfate reduction limits natural arsenic contamination in groundwater. Geology 32, 953-956. doi: 10.1130/G20842.1

Kshetrimayum, K. S., and Hegeu, H. (2016). The state of toxicity and cause of elevated iron and manganese concentrations in surface water and groundwater around Naga Thrust of Assam-Arakan basin, Northeastern India. Environ. Earth Sci. 75:604. doi: 10.1007/s12665-016-5372-4

Kulkarni, H. V., Mladenov, N., Johannesson, K. H., and Datta, S. (2016). Contrasting dissolved organic matter quality in groundwater in Holocene and Pleistocene aquifers and implications for influencing arsenic mobility. Appl. Geochem. 77, 194-205. doi: 10.1016/j.apgeochem.2016.06.002

Lindberg, R. D., and Runnells, D. D. (1984). Ground water redox reactions: an analysis of equilibrium state applied to Eh measurements and geochemical modeling. Science 225, 925-927. doi: 10.1126/science.225.4665.925

Liu, G., Fernandez, A., and Cai, Y. (2011). Complexation of arsenite with humic acid in the presence of ferric iron. Environ. Sci. Technol. 45, 3210-3216. doi: 10.1021/es102931p

Ljung, K. S., Kippler, M. J., Goessler, W., Grander, G. M., Nermell, B. M., and Vahter, M. E. (2009). Maternal and early life exposure to manganese in rural Bangladesh. Environ Sci. Technol. 43, 2595-2601. doi: 10.1021/es803143z

Ljung, K. S., and Vahter, M. (2007). Time to re-evaluate the guideline value for manganese in drinking water? Environ. Health Perspect. 115, 1533-1538. doi: 10.1289/ehp.10316

Loeppert, R. H., and W. P., Inskeep (1996). "Iron," in Methods of Soil Analysis. Part 3. Chemical Methods, SSSA Book Series 5, eds D. L. Sparks, A. L. Page, P. A. Helmke and R. H. Loeppert (Madison, WI: SSSA), 639-664.

Lovley, D. R., Coates, J. D., Blunt-Harris, E. L., Phillips, E. J. P., and Woodward, J. C. (1996). Humic substances as electron acceptors for microbial respiration. Nature 382, 445-448. doi: 10.1038/382445a0

Lovley, D. R., Fraga, J. L., Blunt-Harris, E. L., Hayes, L., Phillips, E. J. P., and Coates, J. D. (1998). Humic substances as a mediator for microbially catalyzed metal reduction. Acta. Hydrochim. Hydrobiol. 26, 152-157.

Lovley, D. R., Fraga, J. L., Coates, J. D., and Blunt-Harris, E. L. (1999). Humics as an electron donor for anaerobic respiration. Environ. Microbiol. 1, 89-98. doi: 10.1046/j.1462-2920.1999.00009.x

Lovley, D. R., and Goodwin, S. (1988). Hydrogen concentrations as an indicator of the predominant terminal electron-accepting reactions in aquatic sediments. Geochim. Cosmochim. Acta 52, 2993-3003. doi: 10.1016/0016-7037(88) 90163-9

Lovley, D. R., Holmes, D. E., and Nevin, K. P. (2004). Dissimilatory $\mathrm{Fe}(\mathrm{III})$ and $\mathrm{Mn}(\mathrm{IV})$ reduction. Adv. Microb. Physiol. 49, 219-286. doi: 10.1016/S0065-2911(04)49005-5

Lovley, D. R., and Phillips, E. J. P. (1988). Novel mode of microbial energy metabolism-organic carbon oxidation coupled to dissimilatory reduction of iron or manganese. Appl. Environ. Microbiol. 54, 1472-1480.

Majumder, S., Datta, S., Nath, B., Neidhardt, H., Sarkar, S., Roman-Ross, G., et al. (2016). Monsoonal influence on variation of hydrochemistry and isotopic signatures: Implications for associated arsenic release in groundwater. J. Hydrol. 535, 407-417. doi: 10.1016/j.jhydrol.2016.01.052

Manning, B. A., Fendorf, S. E., Bostick, B., and Suarez, D. L. (2002). Arsenic (III) oxidation and arsenic (V) adsorption reactions on synthetic birnessite. Environ. Sci. Technol. 36, 976-981. doi: 10.1021/es0110170

Manning, B. A., and Goldberg, S. (1997). Adsorption and stability of arsenic (III) at the clay-mineral-water interface. Environ. Sci. Technol. 31, 2005-2011. doi: $10.1021 /$ es 9608104
Marshall, K. C. (1979). "Biogeochemistry of manganese minerals," in Biogeochemical Cycling of Mineral-Forming Elements, eds P. A. Trudinger and D. J. Swaine (Amsterdam: Elsevier/North Holland Publishing Co.), 253-286.

McArthur, J. M., Banerjee, D. M., Hudson-Edwards, K. A., Mishra, R., Purohit, R., Ravenscroft, P., et al. (2004). Natural organic matter in sedimentary basins and its relation to arsenic in anoxic ground water: the example of West Bengal and its worldwide implications. Appl. Geochem. 19, 1255-1293. doi: 10.1016/j.apgeochem.2004.02.001

McArthur, J. M., Nath, B., Banerjee, D. M., Purohit, R., and Grassineau, N. (2011). Palaeosol control on groundwater flow and pollutant distribution: the example of arsenic. Environ. Sci. Technol. 45, 1376-1383. doi: 10.1021/es1032376

McArthur, J. M., Ravenscroft, P., Banerjee, D. M., Milsom, J., Hudson-Edwards, K. A., Sengupta, S., et al. (2008). How paleosols influence groundwater flow and arsenic pollution: a model from the Bengal Basin and its worldwide implication. Water Resour. Res. 44:W11411. doi: 10.1029/2007WR006552

McArthur, J. M., Ravenscroft, P., Safiullah, S., and Thirlwall, M. F. (2001). Arsenic in groundwater: testing pollution mechanisms for sedimentary aquifers in Bangladesh. Water Resour. Res. 37, 109-117. doi: 10.1029/2000WR900270

McArthur, J. M., Sikdar, P. K., Hoque, M. A., and Ghosal, U. (2012a). Waste-water impacts on groundwater: $\mathrm{Cl} / \mathrm{Br}$ ratios and implications for arsenic pollution of groundwater in the Bengal Basin and Red River Basin, Vietnam. Sci. Total Environ. 437, 390-402. doi: 10.1016/j.scitotenv.2012.07.068

McArthur, J. M., Sikdar, P. K., Nath, B., Grassineau, N., Marshall, J., and Banerjee, D. M. (2012b). Sedimentological Control on Mn, and Other Trace Elements, In Groundwater of the Bengal Delta. Environ. Sci. Technol. 46, 669-676. doi: 10.1021/es202673n

McGuire, J. T., Long, D. T., Klug, M. J., Haack, S. K., and Hyndman, D. W. (2002). Evaluating behavior of oxygen, nitrate and sulfate during recharge and quantifying reduction rates in a contaminated aquifer. Environ. Sci. Technol. 36, 2693-2700. doi: 10.1021/es015615q

McKnight, D. M., Boyer, E. W., Westerhoff, P. K., Doran, P. T., Kulbe, T., and Andersen, D. T. (2001). Spectrofluorometric characterization of dissolved organic matter for indication of precursor organic material and aromaticity. Limnol. Oceanogr. 46, 38-48. doi: 10.4319/lo.2001.46.1.0038

Mladenov, N., Zheng, Y., Miller, M. P., Nemergut, D. R., Legg, T., Simone, B., et al. (2010). Dissolved organic matter sources and consequences for iron and arsenic mobilzation in Bangladesh aquifers. Environ. Sci. Technol. 44, 123-128. doi: $10.1021 /$ es $901472 \mathrm{~g}$

Mladenov, N., Zheng, Y., Simone, B., Bilinksi, T. M., McKnight, D. M., Nemergut, D., et al. (2015). Dissolved organic matter quality in a shallow aquifer of Bangladesh: implications for arsenic mobility. Environ. Sci. Technol. 49, 10815-10824. doi: 10.1021/acs.est.5b01962

Mohajerin, T., Neal, A. W., Telfeyan, K., Sankar, M. S., Ford, S., Yang, N., et al. (2014). Geochemistry of tungsten and arsenic in aquifer systems: a comparative study of groundwaters from West Bengal, India, and Nevada, USA. Wat. Air. Soil. Poll. 225, 1792. doi: 10.1007/s11270-013-1792-x

Morgan, J. J., and Stumm, W. (1964). The role of multivalent metal oxides in limnological transformations as exemplified by iron and manganese. J. Water Poll. Contr. Fed. 36, 276-277.

Mukherjee, A. B., and Bhattacharya, P. (2001). Arsenic in groundwater in the Bengal Delta Plain: slow poisoning in Bangladesh. Environ. Rev. 9, 189-220. doi: 10.1139/a01-007

Mukherjee, A., Fryar, A. E., and Howell, P. D. (2007). Regional hydrostratigraphy and groundwater flow modeling in the arsenic-affected areas of the western Bengal basin, West Bengal, India. Hydrogeology 15, 1397-1418. doi: 10.1007/s10040-007-0208-7

Nath, B., Chakraborty, S., Burnol, A., Stüben, D., Chatterjee, D., and Charlet, L. (2009). Mobility of arsenic in the sub-surface environment: an integrated hydrogeochemical study and sorption model of the sandy aquifer materials. $J$. Hydrol. 364, 236-248. doi: 10.1016/j.jhydrol.2008.10.025

Nealson, K. H., and Saffarini, D. (1994). Iron and manganese in anaerobic respiration: environmental significance, physiology, and regulation. Ann. Rev Microbiol. 48, 311-343. doi: 10.1146/annurev.mi.48.100194.001523

Neidhardt, H., Biswas, A., Freikowski, D., Majumder, S., Chetterjee, D., and Berner, Z. A. (2013). Reconstructing the sedimentation history of the Bengal Delta Plain by means of geochemical and stable isotopic data. Appl. Geochem. 36, 70-82. doi: 10.1016/j.apgeochem.2013.06.017 
Nickson, R. T., McArthur, J. M., Burgess, W. G., Ahmed, K. M., Ravenscroft, P., and Rahman, M. (1998). Arsenic poisoning in Bangladesh groundwater. Nature 395:338. doi: $10.1038 / 26387$

Nickson, R. T., McArthur, J. M., Ravenscroft, P., Burgess, W. G., and Ahmed, K. M. (2000). Mechanism of arsenic release to groundwater, Bangladesh and West Bengal. Appl. Geochem. 15, 403-413. doi: 10.1016/S0883-2927(99)00086-4

Ohno, T. (2002). Response to comment on "Fluorescence inner-filtering correction for determining the humification index of dissolved organic matter". Environ. Sci. Technol. 36:4196. doi: 10.1021/es020113d

Ono, K., Komai, K., and Yamada, M. (2002). Myoclonic involuntary movement associated with chronic manganese poisoning. J. Neurol. Sci. 199, 93-96. doi: 10.1016/S0022-510X(02)00111-9

Oscarson, D. W., Huang, P. M., Defosse, C., and Herbillon, A. (1981). Oxidative power of $\mathrm{Mn}(\mathrm{IV})$ and $\mathrm{Fe}(\mathrm{III})$ oxides with respect to $\mathrm{As}(\mathrm{III})$ in terrestrial and aquatic environments. Nature 291, 50-51. doi: 10.1038/291050a0

Parlanti, E., Worz, K., Geoffroy, L., and Lamotte, M. (2000). Dissolved organic matter fluorescence spectroscopy as a tool to estimate biological activity in a coastal zone submitted to anthropogenic inputs. Org. Geochem. 31, 1765-1781. doi: 10.1016/S0146-6380(00)00124-8

Postma, D., and Jakobsen, R. (1996). Redox zonation: equilibrium constraints on the $\mathrm{Fe}(\mathrm{III}) / \mathrm{SO}_{4}^{2-}$ - reduction interface. Geochim. Cosmochim. Acta 60, 3169-3175. doi: 10.1016/0016-7037(96)00156-1

Premarathna, H. L., McLaughlin, M. J., Kirby, J. K., Hettiarachchi, G. M., Beak, D., Stacey, S., et al. (2010). Potential availability of fertilizer selenium in field capacity and submerged soils. Soil Sci. Soc. Am. J. 74, 1589-1596. doi: 10.2136/sssaj2009.0416

Ravenscroft, P., Burgess, W. G., Ahmed, K. M., Burren, M., and Perrin, J. (2005). Arsenic in groundwater of the Bengal Basin, Bangladesh: Distribution, field relations, and hydrogeological setting. Hydrogeol. J. 13, 727-751. doi: 10.1007/s10040-003-0314-0

Rittman, B. E., and McCarty, P. L. (2001). Environmental Biotechnology: Principles and Applications. Boston, MA: McGraw-Hill Higher Education.

Roychowdhury, T., Uchino, T., Tokunaga, H., and Ando, M. (2002). Arsenic and other heavy metals in soils from an arsenic-affected area of West Bengal, India. Chemosphere 49, 605-618. doi: 10.1016/S0045-6535(02)00309-0

Sankar, M. S. (2013). Geochemical Significance of Arsenic and Manganese Toxicity in Groundwaters from Murshidabad District, West Bengal, India, [master's thesis]. Manhattan, KS: Kansas State University.

Sankar, M. S., Vega, M. A., Defoe, P. P., Kibria, M. G., Ford, S., Telfeyan, K., et al. (2014). Elevated arsenic and manganese in groundwaters of Murshidabad, West Bengal, India. Sci. Tot. Environ. 488-489, 570-579. doi: 10.1016/j.scitotenv.2014.02.077

Scott, D. T., McKnight, D. M., Blunt-Harris, E. L., Kolesar, S. E., and Lovley, D. R. (1998). Quinone moieties act as electron acceptors in the reduction of humic substances by humics-reducing microorganisms. Environ. Sci. Technol. 32, 2984-2989. doi: 10.1021/es980272q

Sharma, P., Ofner, J., and Kappler, A. (2010). Formation of binary and ternary colloids and dissolved complexes of organic matter, Fe and As. Environ. Sci. Technol. 44, 4479-4485. doi: 10.1021/es100066s

Shrivastava, A., Barla, A., Yadav, H., and Bose, S. (2015). Arsenic contamination in shallow groundwater and agricultural soil of Chakdaha block, West Bengal, India. Front. Environ. Sci. 2:50. doi: 10.3389/fenvs.2014.00050

Smedley, P. L., and Kinniburgh, D. G. (2002). A review of the source, behaviour and distribution of arsenic in natural waters. Appl. Geochem. 17, 517-568. doi: 10.1016/S0883-2927(02)00018-5

Spangler, A. H., and Spangler, J. G. (2009). Groundwater manganese and infant mortality rate by county in North fCarolina: an ecological analysis. EcoHealth 6, 596-600. doi: 10.1007/s10393-010-0291-4

Spencer, R. G. M., Bolton, L., and Baker, A. (2007). Freeze/thaw and pH effects on freshwater dissolved organic matter fluorescence and absorbance properties from a number of UK locations. Water Res. 41, 2941-2950. doi: 10.1016/j.watres.2007.04.012

Stedmon, C. A., and Bro, R. (2008). Characterizing dissolved organic matter fluorescence with parallel factor analysis: a tutorial. Linmol. Oceanagr. Methods 6, 572-579. doi: 10.4319/lom.2008.6.572

Stedmon, C. A., Markager, S., and Bro, R. (2003). Tracing dissolved organic matter in aquatic environments using a new approach to fluorescence spectroscopy. Mar. Chem. 82, 239-254. doi: 10.1016/S0304-4203(03)00072-0
Stefansson, A., Arnorsson, S., and Sveinbjörnsdottir, A. E. (2005). Redox reaction and potentials in natural water at disequilibrium. Chem. Geol. 221, 289-311. doi: 10.1016/j.chemgeo.2005.06.003

Stollenwerk, K. G., Breit, G. N., Welch, A. H., Yount, J. C., Whitney, J. W., Foster, A. L., et al. (2007). Arsenic attenuation by oxidized aquifer sediments in Bangladesh. Sci. Tot. Environ. 379, 133-150. doi: 10.1016/j.scitotenv.2006.11.029

Stumm, W., and Morgan, J. J. (1981). Aquatic Chemistry: Chemical Equilibria and Rates in Natural Waters. New York, NY: Wiley.

Sun, X., Doner, H. E., and Zavarin, M. (1999). Spectroscopy study of arsenite oxidation on Mn-xubstituted goethite. Clays Clay Minerals 47, 474-480. doi: 10.1346/CCMN.1999.0470409

Sunda, W. G., and Kieber, D. J. (1994). Oxidation of humic substances by manganese oxides yields low-molecular-weight organic substrates. Nature 367, 62-64. doi: 10.1038/367062a0

Tebo, B. M., Bargar, J. R., Clement, B. G., Dick, G. J., Murray, K. J., Parker, D., et al. (2004). Biogenic manganese oxides: properties and mechanisms of formation. Annu. Rev. Earth Planet. Sci. 32, 287-328. doi: 10.1146/annurev.earth.32.101802.120213

Tebo, B. M., Clement, B. G., Dick, G. J., Hurst, C. J., Crawford, R. L., Garland, J. L., et al. (2007). "Biotransformations of manganese," in Manual of Environmental Microbiology, 3rd Edn., eds C. J. Hurst, R. L. Crawford, J. L. Garland, D. A. Lipson, A. L. Mills, and L. D. Stetzenbach (Washington, DC: ASM Press) 1223-1238. doi: 10.1128/9781555815882.ch100

Tebo, B. M., Ghiorse, W. C., van Waasbergen, L. G., Siering, P. L., and Caspi, R. (1997). "Bacterially-mediated mineral formation: insights into manganese(II) oxidation from molecular genetic and biochemical studies," in Geomicrobiology: Interactions Between Microbes and Minerals, eds J. F. Banfield and K. H. Nealson (Washington, DC: Mineralogical Society of America), 225-266.

Toner, B., Manceau, A., Webb, S. M., and Sposito, G. (2006). Zinc sorption to biogenic hexagonal-birnessite particles within a hydrated bacterial biofilm. Geochim. Cosmochim. Acta 70, 27-43. doi: 10.1016/j.gca.2005.08.029

Tournassat, C., Charlet, L., Bosbach, D., and Manceau, A. (2002). Arsenic(III) oxidation by birnessite and precipiation of manganese(II) arsenate. Environ. Sci. Technol. 36, 493-500. doi: 10.1021/es0109500

Tupas, L. M., Popp, B. N., and Karl, D. M. (1994). Dissolved organic carbon in oligotrophic waters: experiments on sample preservation, storage, and analysis. Mar. Chem. 45, 207-216. doi: 10.1016/0304-4203(94)90004-3

van Geen, A., Zheng, Y., Versteeg, R., Stute, M., Horneman, A., Dhar, R., et al. (2003). Spatial variability of arsenic in 6000 tube wells in a $25 \mathrm{~km}^{2}$ area of Bangladesh. Water Resour. Res. 39:1140. doi: 10.1029/2002WR001617

Vodyanitskii, Y. N. (2009). Mineralogy and geochemistry of manganese: a review of publications. Eurasian Soil Sci. 42, 1170-1178. doi: 10.1134/S1064229309100123

von Brömssen, M., Jakariya, M., Bhattacharya, P., Ahmed, K. M., Hasan, M. A., Sracek, O., et al. (2007). Targeting low-arsenic aquifers in groundwater of Matlab, Upazila, Southeastern Bangladesh. Sci. Tot. Environ. 379, 121-132. doi: 10.1016/j.scitotenv.2006.06.028

von Brömssen, M., Larsson, S. H., Bhattacharya, P., Hasan, M. A., Ahmed, K. M., Jakariya, M., et al. (2008). Geochemical characterization of shallow aquifer sediments of Matlab Upazila, Southeastern Bangladesh implications for targeting low-As aquifers. J. Cont. Hydrol. 99, 137-149. doi: 10.1016/j.jconhyd.2008.05.005

Wasserman, G. A., Liu,. X., Factor-Litvak,. P., Gardner,. J. M., and Graziano,. J. H. (2008). Developmental impacts of heavy metals and undernutrition. Basic Clin. Pharmacol. Toxicol. 102, 212-217. doi: 10.1111/j.1742-7843.2007.00187.x

Wasserman, G. A., Liu, X., Parvez, F., Ahsan, H., Levy, D., Factor-Litvak, P., et al. (2006). Water manganese exposure and children's intellectual function in Araihazar, Bangladesh. Environ. Health Perspect. 114:124. doi: 10.1289/ehp.8030

Wasserman, G. A., Liu, X., Parvez, F., Factor-Litvak, P., Ahsan, H., Levy, D., et al. (2011). Arsenic and manganese exposure and children's intellectual function. Neurotoxicology 32, 450-457. doi: 10.1016/j.neuro.2011.03.009

Weishaar, J. L., Aiken, G. R., Bergamaschi, B., Fram, M. S., Fujii, R., and Mopper, K. (2003). Evaluation of specific ultraviolet absorbance as an indicator of the chemical composition and reactivity of dissolved organic carbon. Environ. Sci. Technol. 37, 4702-4708. doi: 10.1021/es030360x 
Wersin, P., Charlet, L., Karthein, R., and Stumm, W. (1989). From adsorption to precipitation: sorption of $\mathrm{Mn}(\mathrm{II})$ on FeCO3(s). Geochim. Cosmochim. Acta 53, 2787-2796. doi: 10.1016/0016-7037(89)90156-7

Williams, C. J., Frost, P. C., and Xenopoulos, M. A. (2013). Beyond best management practices: pelagic biogeochemical dynamics in urban stormwater ponds. Ecol. App. 23, 1384-1395. doi: 10.1890/12-0825.1

Wilson, H. F., and Xenopoulos, M. (2008). Effects of agricultural land use on the composition of fluvial dissolved organic matter. Nat. Geosci. 2, 37-41. doi: 10.1038/ngeo391

Wolf, M., Kappler, A., Jiang, J., and Meckenstock, R. U. (2009). Effects of humic substances and quinones at low concentrations on ferrihydrite reduction by Geobacter metallireducens. Environ. Sci. Technol. 43, 5679-5685. doi: $10.1021 /$ es $803647 \mathrm{r}$

Wood, R. J. (2009). Manganese and birth outcome. Nutr. Rev. 57, 415-420. doi: 10.1111/j.1753-4887.2009.00214.x

Woolf, A., Wright, R., Amarasiriwardena, C., and Bellinger, D. (2002). A child with chronic manganese exposure from drinking water. Environ. Health Perspect. 110:613. doi: 10.1289/ehp.02110613

World Health Organization (2011). Guidelines for Drinking-Water Quality, 4th Edn. Geneva: WHO.

Wu, Y., Li, W., and Sparks, D. (2015). The effects of iron(II) on the kinetics of arsenic oxidation and sorption on manganese oxides. J. Colloid Interface Sci. 457, 319-328. doi: 10.1016/j.jcis.2015.07.022

Yazbeck, C., Moreau, T., Sahuquillo, J., Takser, L., and Huel, G. (2006). Effect of maternal manganese blood levels on erythrocyte calcium-pump activity in newborns. Sci. Tot. Environ. 354, 28-34. doi: 10.1016/j.scitotenv.2004.12.012
Ying, S. C., Kocar, B. D., Griffis, S. D., and Fendorf, S. (2011). Competitive microbially and $\mathrm{Mn}$ oxide mediated redox processes controlling arsenic speciation and partitioning. Environ. Sci. Technol. 45, 5572-5579. doi: $10.1021 /$ es $200351 \mathrm{~m}$

Young, L. B., and Harvey, H. H. (1992). The relative importance of manganese and iron oxides and organic matter in the sorption of trace metals by surficial lake sediments. Geochim. Cosmochim. Acta 56, 1175-1186. doi: 10.1016/0016-7037(92)90055-N

Zota, A. R., Ettinger, A. S., Bouchard, M., Amarasiriwardena, C. J., Schwartz, J. $\mathrm{Hu}, \mathrm{H}$., et al. (2009). Maternal blood manganese levels and infant birth weight. Epidemiology 20, 367-373. doi: 10.1097/EDE.0b013e31819b93c0

Zsolnay, A. (2003). Dissolved organic matter: artefacts, definitions, and functions. Geoderma 113, 187-209. doi: 10.1016/S0016-7061(02) 00361-0

Conflict of Interest Statement: The authors declare that the research was conducted in the absence of any commercial or financial relationships that could be construed as a potential conflict of interest.

Copyright (C) 2017 Vega, Kulkarni, Mladenov, Johannesson, Hettiarachchi, Bhattacharya, Kumar, Weeks, Galkaduwa and Datta. This is an open-access article distributed under the terms of the Creative Commons Attribution License (CC BY). The use, distribution or reproduction in other forums is permitted, provided the original author(s) or licensor are credited and that the original publication in this journal is cited, in accordance with accepted academic practice. No use, distribution or reproduction is permitted which does not comply with these terms. 